This item was submitted to Loughborough's Research Repository by the author.

Items in Figshare are protected by copyright, with all rights reserved, unless otherwise indicated.

\title{
The effectiveness of interventions to increase physical activity among adolescent girls: A meta-analysis
}

PLEASE CITE THE PUBLISHED VERSION

http://dx.doi.org/10.1016/j.acap.2014.08.009

\section{PUBLISHER}

(C) Elsevier

VERSION

AM (Accepted Manuscript)

\section{PUBLISHER STATEMENT}

This work is made available according to the conditions of the Creative Commons Attribution-NonCommercialNoDerivatives 4.0 International (CC BY-NC-ND 4.0) licence. Full details of this licence are available at: https://creativecommons.org/licenses/by-nc-nd/4.0/

\section{LICENCE}

CC BY-NC-ND 4.0

\section{REPOSITORY RECORD}

Pearson, Natalie, Rock Braithwaite, and Stuart J.H. Biddle. 2019. "The Effectiveness of Interventions to Increase Physical Activity Among Adolescent Girls: A Meta-analysis”. figshare. https://hdl.handle.net/2134/20307. 
Published as: Pearson, N. L., Braithwaite, R., \& Biddle, S. J. H. (2015). The effectiveness of interventions to increase physical activity among adolescent girls: a meta-analysis. Academic Pediatrics, 15, 9-18. doi:http://dx.doi.org/10.1016/j.acap.2014.08.009

The effectiveness of interventions to increase physical activity among adolescent girls: A meta-analysis

$$
\begin{aligned}
& \text { Natalie Pearson }^{1} \\
& \text { Rock Braithwaite }^{3} \\
& \text { Stuart JH Biddle }{ }^{124}
\end{aligned}
$$

${ }^{1}$ School of Sport, Exercise \& Health Sciences, Loughborough University, UK

2 The NIHR Leicester-Loughborough Diet, Lifestyle and Physical Activity Biomedical Research Unit, UK

${ }^{3}$ Department of Kinesiology and Recreation Administration, Humboldt State University, Arcata, CA, USA

${ }^{4}$ Now at Institute of Sport, Exercise \& Active Living, Victoria University, Australia

Running Title: Adolescent girls’ physical activity

Key words: adolescent, adolescent behavior, girls, female, physical activity, motor activity, sedentary lifestyle, exercise, health behavior, intervention studies, meta-analysis

Correspondence:

Professor Stuart Biddle

Professor of Active Living \& Public Health

Institute of Sport, Exercise \& Active Living (ISEAL)

Victoria University

Footscray Park

Melbourne, VIC 8001

Australia

E: stuart.biddle@vu.edu.au 


\section{What this systematic review adds}

- This is the first meta-analysis to be conducted on physical activity interventions on adolescent girls.

- The overall effect size was small but significant and shows that physical activity behaviour change is possible but likely to be challenging

- Stronger intervention effects were found for multi-component interventions, interventions based on theory, and those with moderate study quality. 


\begin{abstract}
Objective. Research has shown that a clear decline in physical activity among girls starting in early adolescence. Therefore, adolescent girls have been identified as a key target population for physical activity behaviour change. The quantification of intervention effectiveness for this group has not been previously reported in a meta-analysis, and therefore this is the objective of the current meta-analysis.
\end{abstract}

Study Selection. Included were interventions in which the main component, or one of the components, was aimed at promoting physical activity through behaviour change in any setting. Interventions had to include a non-physical activity control group or comparison group, and include a quantitative outcome assessment of physical activity behaviour in girls aged 12-18 years.

Data Sources. Science Direct, PubMed, PsychINFO, Web of Science, Cochrane Libraries, and EPPI Centre databases were searched up to and including May 2013.

Data Extraction and Synthesis. Forty-five studies ( $k=34$ independent samples) were eligible from an initial 13,747 references. A random-effects meta-analysis was conducted.

Results. The average treatment effect for adolescent girls involved in physical activity interventions was significant but small $(g=0.350,95 \%$ C.I. $=0.12,0.58, \mathrm{p}<.001)$. Moderator analyses showed larger effects for interventions that were theory based, performed in schools, were girls-only, with younger girls, used multicomponent strategies, and involved targeting both physical activity and sedentary behaviour.

Conclusions and Relevance. Interventions to increase physical activity in adolescent girls show small but significant effects, suggesting that behaviour change may be challenging. Results suggest some approaches that appear to be successful. 
Given the well documented health benefits of physical activity and concerns about low levels of physical activity in all age groups, there is a clear need for effective interventions that increase population levels of physical activity ${ }^{1}$. Recent studies have shown that the decline in physical activity during adolescence is significant for both girls and boys, and that the decline among girls begins in early adolescence ${ }^{2}$. Given this evidence, and that physical activity tracks in a small to moderate way from adolescence into adulthood ${ }^{3}$, it is important that we better understand how to increase physical activity in adolescent girls.

One of the first reviews of the effects of physical activity interventions in young people was reported by Stone et al. ${ }^{4}$ They recommended that future research involve studies that investigate the success of interventions that attempt to prevent the decline in physical activity in females and adolescents. Ringuet and Trost ${ }^{5}$ have suggested that community-based interventions for older adolescents should be a priority, and this can include girls. The most comprehensive review to date is that by van Sluijs and colleagues ${ }^{6}$. Interventions conducted with adolescents generally showed no or inconclusive effectiveness; only two categories ('school plus community plus family' and 'multicomponent') showed 'strong' evidence for effectiveness. However, only eight of the included studies were exclusively on girls. Moreover, in studies that included both boys and girls, results for girls were not reported separately.

Camacho-Miano et al. ${ }^{7}$ reported effects for young and adolescent girls, but only included those studies that focused on girls alone, thus making no distinction between those interventions focusing on girls alone and those that mixed boys and girls. While we know that physical activity levels of boys and girls differ, we do not yet know whether targeting girls 
alone is more effective than mixed interventions. The purpose of this meta-analysis, therefore, is to quantify the effect of physical activity interventions on adolescent girls by including all intervention studies that provided results for girls separately and compared an intervention with a control or non-physical activity comparison. This was from girls-only studies as well as boys and girls in the same study but where data on girls were reported separately. This is the first such meta-analysis.

\section{Methods}

Methods were adopted as reported in a parallel paper where further details can be found ${ }^{8}$.

\section{Eligibility criteria and study selection}

For inclusion, research papers were required to (i) be an intervention study in which the main component was aimed at promoting physical activity; (ii) include adolescent girls aged 12-18 years (or a mean within these ranges) as participants of a study at baseline; (iii) include a non-physical activity control group or comparison group (randomised or nonrandomised); (iv) include a quantitative assessment of physical activity; (v) be published in English up to and including May 2013. The majority of published papers are likely to be in English and we did not have the necessary range of language skills to go beyond English. A comprehensive and representative coverage of the grey literature cannot be guaranteed and so we made the decision to review only peer-reviewed published work. Study samples, not papers, were the unit of analysis.

Potentially relevant research papers were selected by screening titles, then abstracts and, if required, the entire article. One author conducted this element with one other independently reviewing $20 \%$. 


\section{Data extraction and coding}

Information extracted (e.g., sample characteristics) can be seen in Tables 1 and 2.

Information about outcomes, including means and associated SDs and mean change from baseline to post-test, were extracted for use in calculating effect sizes.

\section{Data sources and search strategy}

Search strategies were built around four groups of keywords: population, study design, behaviour, and intervention type. Key words used to guide the searching process included 'girls’, ‘youth’, ‘children’, ‘adolescents’, ‘teens’, ‘teenagers’, ‘young people’, ‘controlled trial', 'random', ‘intervention', 'prospective', ‘trial', 'cluster', ‘physical activity’, 'activities’, 'exercise’, 'physical education’, 'play’, 'leisure’, ‘sport', 'school’, ‘community’, 'family’, 'primary health care’, ‘counselling', ‘education’. Science Direct, PubMed, PsychINFO, Web of Science, Cochrane Libraries, and EPPI Centre databases were searched. Manual searches of personal files were conducted along with screening of reference lists of previous reviews ${ }^{67}$ 9-21. An example search strategy is shown in Figure 1.

\section{Risk of Bias}

The Cochrane Collaboration tool for Assessing Risk of Bias was used to assess studies ${ }^{22}$. Seven domains were scored with high, low or unclear risk for bias: sequence generation, allocation concealment, blinding of participants and personnel, blinding of outcome assessment, incomplete outcome data, selective outcome reporting and 'other' issues (similarity in baseline characteristics and timing of outcome assessment). The assessment was performed independently by the first and third authors and the findings were discussed until consensus was achieved. Each domain was scored as -1 for high risk, 0 for unclear risk and 1 
for low risk. Scores were summed with a possible range of scores from -6 to 6 ('other' was not scored), with positive values meaning lower risk of bias.

\section{Data Integration}

Data were screened for outliers and publication bias. Potential outliers were assessed as having relative residual scores (z-scores) that were less or greater two SDs above or below the mean effect size. If studies exceeded the criterion standard a sensitivity analysis was conducted to determine how overall results would change should an outlier be retained or removed $^{23}$. Studies were retained when overall results remained within the $95 \%$ confidence interval and the effect size was significant. Publication bias or "file drawer problem" refers to inclusion or exclusion of published or unpublished studies that could produce a biased review $^{24} 25$. Three standard techniques were used to marginalize the effects of publication bias including review of the funnel plot $^{26}$, Fail-Safe $N$ calculation ${ }^{25}$, and a "Trim and Fill” procedure $^{2728}$.

\section{Effect Size Calculations}

Comprehensive Meta-Analysis software (version-2) was used to perform calculations ${ }^{29}$. Baseline and post-intervention means (SD) were used to calculate the study effect size. When unavailable, post-intervention means (SD), mean change in each group, or adjusted differences after the intervention were used. When key information was missing from an article, as was the case in 6 out of 48 eligible studies, three attempts were made to reach the corresponding author via e-mail before using the available data or eliminating the study from the analysis. 
An inverse variance weighting procedure for independent effect sizes was used to improve overall precision $^{3031}$. Cooper's shifting unit of analysis approach was also applied to provide flexibility in reporting outcomes and minimize a violation of the independence statistical assumption $^{32}$. Hedges' $g$ was the effect size metric selected ${ }^{33}$ and is recommended when there are fewer than 20 studies to prevent underestimation of effect size ${ }^{34}$. The overall sample size $(\mathrm{k}=34)$ exceeded the recommended guidelines, however, moderator analyses compared smaller subgroups $(\mathrm{k}<4)$ and, to ensure consistency in reporting methods, Hedges’ $g$ was selected.

\section{Random Effects Model}

A random effects model was selected to represent the data due to the variability between interventions being employed to measure physical activity in adolescent girls ${ }^{35-37}$.

\section{Subgroup Analyses}

Subgroup (moderator) analyses were conducted ${ }^{38}$ to test for differences between a number of levels of independent variables (i.e., Intervention type, Intervention quality). Assessment of data homogeneity was performed using the three test statistics of $Q$-value, tau-squared $\left(\tau^{2}\right)$ value, and I-squared $\left(I^{2}\right)$-value to provide an overall interpretation. The rationale for including three separate statistics is that significant $Q$-values only indicate between study variance and not the magnitude of dispersion ${ }^{39}$. Initial evaluation of the data distribution is based on a significant $(p<.05)$ total $Q$-value $\left(Q_{T}\right)$ and indicates a heterogeneous distribution. The $\tau^{2}$-value quantifies between study variance and larger values reflect true differences between studies. To complete the interpretation of heterogeneity an $I^{2}$-value provides information about the amount of variance (confidence interval overlap) that can be explained by analyzing covariates ${ }^{40}$. When $I^{2}$-values exceed 50 percent, or moderate levels of relative 
variance $^{40}$, additional statistical techniques resembling t-test or ANOVA are required to determine differences between covariates ${ }^{33}$.

\section{Results}

Figure 2 shows the flow chart of sample extraction with 48 studies meeting inclusion criteria, resulting in 37 independent samples. Three studies were excluded because data were unavailable ${ }^{41-43}$. Forty five studies were included in the analysis (34 independent samples; k).

Table 1 describes the interventions included in the meta-analysis and Table 2 provides the coding according to the three categories of intervention, sample and study characteristics. A total of 5680 adolescent girls were exposed to physical activity treatment conditions compared to 5126 in control conditions. Cohen's ${ }^{44}$ criteria for small $(>.20)$, moderate $(>.50)$, and large $(>.80)$ effect sizes were used for interpretation. Positive effect sizes were indicative of treatment or experimental groups having higher physical activity scores.

Screening for outliers found two studies reported in four separate papers ${ }^{45-48}$ with relative residual (z-score) values greater than two, therefore a sensitivity analysis was conducted. Both studies were retained as the overall effect size from removing either study would have been marginal $(-0.045)$, remaining significant $(p<.001)$ and within the $95 \%$ confidence interval. Publication bias was unlikely as there was a balanced distribution of studies in the funnel plot, no studies were added in the “Trim and Fill” procedure, and a Fail Safe N calculation that determined 3476 studies were needed to nullify significant results.

\section{Treatment Effects for Physical Activity}


The average treatment effect was significant but small $(g=0.350,95 \%$ C.I. $=0.12,0.58, \mathrm{p}<$ .001). Results suggest that adolescent girls exposed to physical activity intervention treatments participated in more physical activity (self-reported or measured minutes/hours) than girls in control conditions equivalent to about one-third of a standard deviation in magnitude. Another interpretation of the difference between experimental and control groups using $\mathrm{z}$ as standard score would be that adolescent girls exposed to experimental physical activity treatments engaged in approximately 13.68\% more physical activity than adolescent girls in control conditions. A large $Q_{T}$-value (1436.90) suggested that the effect size distribution was heterogeneous. Review of the two additional homogeneity statistics found a sizeable between study variance $\left(\tau^{2}=.421\right)$ and a large portion of variance $\left(I^{2}=98\right)$ could be explained by performing a subgroup (moderator) analysis of covariates. Figure 3 provides the summary and individual study data in a forest plot.

\section{Subgroup Analyses}

Homogeneity statistics provided evidence for the diversity of interventions. Based on the significant heterogeneous distribution, moderator (subgroup) differences were analysed. Table 3 provides the subgroup analyses for intervention, sample and study characteristics. Results between subgroups were not significant for any of the subgrouping variables; however, there were several trends. Conservative interpretations should be applied to subgroup analyses that contain fewer than five studies ${ }^{39}$.

Intervention characteristics that provided small to moderate trends were multicomponent interventions $(k=9, g=.618, p<.01)$, interventions focusing on both physical activity and sedentary behaviours $(k=4, g=.73, p<.01)$, theory based interventions ( $k=21, g=.42, p$ $<.01)$, and intervention designs of high quality $(k=4, g=.524, p<.05)$. Sample 
characteristics with significant trends included interventions that were applied to girls only $(k$ $=19, g=.439, p<.01)$, interventions designed for younger adolescent girls $(k=22, g=.360$, $p<.05$ ), and interventions that were conducted within the United States $(k=22, g=.394, p$ $<.05)$. Study characteristics that produced significant trends included interventions conducted in school-based settings $(k=19, g=.427, p<.05)$ and where physical activity was assessed by self-report $(k=26, g=.380, p<.05)$. Each of the significant trends for all three categories had large $\tau^{2}$ and $I^{2}$ values which is indicative of a large variance between studies within a subgroup.

\section{Discussion}

We conducted a meta-analysis of physical activity interventions that included data for adolescent girls. This follows our previous similar review focussing on pre-adolescent girls ${ }^{8}$. The overall effect size was small but significant and can be interpreted in several ways. First, it shows that physical activity behaviour change is possible for adolescent girls and is broadly comparable to other physical activity intervention effects across other age groups and settings ${ }^{49}$. For example, an early meta-analysis of physical activity interventions in boys and girls reported an effect size of 0.47 across 10 studies $^{5}$, and a more recent review of afterschool interventions showed an effect size of $0.44^{50}$. Our recent meta-analysis of interventions for pre-adolescent girls reported an ES of $0.31^{8}$. It therefore appears that our meta-analytic findings are broadly comparable to other analyses in respect of the strength of effect of behaviour change.

Second, our data suggest that the effect is modest and therefore indicative that behaviour change may be challenging. Contemporary environments often inhibit physical activity and, 
at the same time, sedentary behaviours have become habitual, socially normative and often highly reinforcing. However potent some interventions might try to be, they are taking place against the tide of an unhelpful environment. Small effects, therefore, could be seen as encouraging.

The meta-analysis shows that the overall effect is highly heterogeneous. This is not surprising given the diversity of approaches adopted. Consequently, it is necessary to document the effects of potential moderators. Regarding intervention characteristics, stronger effects were found for multi-component interventions (moderate effect), interventions based on theory (small-to-moderate), and those with moderate study quality (moderate). A large effect was found for interventions that targeted both physical activity and sedentary behaviour but this should be treated with some caution as only three studies were included. Multi-component interventions were also found to have strong effects in the systematic review by van Sluijs et $\mathrm{al}^{6}$ and our review of pre-adolescent girls ${ }^{8}$. The make-up of multicomponent interventions included strategies that targeted dietary, physical activity, and sedentary behaviours using a number of methods to target and change unhealthy patterns. Methods used to decrease undesirable behaviours contained combinations of support components (i.e., family, friends, etc.), individual components (i.e., specifically tailored programs for individuals/groups), choice components (different options to facilitate behaviour change), and educational and environmental components targeting during and after school behaviours. Multicomponent interventions were designed to provide comprehensive programs that facilitate changes in behaviour in a multitude of ways and as a result were almost twice as effective when compared with programs designed to focus on singular components. This suggests that 
different agencies might need to work together more, such as schools, community and parent groups, and not just rely on one setting, such as the school or family.

Basing an intervention on theory produced slightly stronger effects than the overall mean. This was not the case for our review on pre-adolescent girls, suggesting that theory may be less relevant for younger ages. Theory-based interventions may allow for the identification of 'active ingredients' in an intervention and for better explanations of intervention effects through mediators and moderators ${ }^{51}$. The predominant theory used as a basis for interventions was Social Cognitive Theory ${ }^{52}$. Others identified included the Trans-Theoretical Model, Intervention Mapping, Behavioural Determinants, Behavioural Choice, Health Promotion Model, and Social Learning Theory.

High quality studies produced the largest effects, however, there were insufficient studies (k =4) to drawn any firm conclusions. What is challenging is that the confidence interval and subsequent homogeneity statistics have large variability. Physical activity interventions that were designed and representative of both low and moderate quality provide evidence that improvements in physical activity behaviours in adolescent girls produce small to moderate effects, however, the most promising results may be connected to rigorous and controlled interventions that are able to explain larger portions of variance.

A higher effect was also seen for school-based interventions. This was the only study characteristic showing a signficant moderating effect. School-based interventions have the advantage of a supportive physical environment, easy access to recruitment and 
availability of professional staffing. Future school-based studies might need to take further account of the needs of adolescent girls and ensure that extra-curricula physical activity is appealing and not simply a repetition of existing activities from physical education, some of which may be more appealing to boys. Involvement of the adolescent girls in the planning of such programmes is essential. Moreover, health professionals from outside education could play a valuable role, including physical therapists and dieticians.

Finally, higher sample characteristic effects were noted for interventions that targetted girls only, young adolescent girls, and were conducted in the US. The latter cannot be explained easily and may be accounted for through specific cultural factors or the lack of compulsory school physical education which has the potential to produce greater intervention effects. However, the additional benefit afforded by having girls take part separately from boys is an interesting issue. It appears that girls may prefer being in classes with their same-sex peers. This could be because some may be inhibited in classes where boys also take part, coupled with some boys possibly dominating certain activities. Moreover, research has shown that girls may be sensitive to issues of body image and self-presentation while being active in mixed-sex environments ${ }^{53}$. For example, feelings of social physique anxiety may be heightened and is much more likely for girls of this age. By having separate classes, these issues are eliminated or diminished. The stronger effects for younger girls may be the result of this age group still being maleable for behaviour change. 
It should also be noted that self-reported physical activity showed a higher effect size than objective measures or self-report and objective combined, although the latter two had very few studies. Self-reported physical activity for adolescents often shows weak validity due to recall bias and error. Whether this has inflated the effect remains to be seen, but it is a slight concern that the six interventions using objective assessment showed a smaller effect size.

The limitations of this review include the over-reliance on studies that are of low-moderate quality, the use of self-report measures for physical activity and the under-representation of studies set in the community or home and from the rest of the World compared to those from the US. Insufficient data can also influence the estimate of effect size and there were several studies that failed to report baseline information or only reported data that were significant. Even though a thorough analysis for publication bias was conducted, the authors acknowledge that bias is always possible when determining and setting inclusion criteria.

Overall, the meta-analysis shows that physical activity interventions for adolescent girls are effective but the effect is small. Subgroup analyses suggest that greater effectiveness appears to result from interventions that are multi-component, theory based, school based, with girls only or with younger adolescent girls, and target both physical activity and sedentary behaviour. Future research should focus on filling the gaps identified in this review, such as the lack of high quality studies and studies in the home setting. Future studies should aim to strengthen the evidence base for interventions among adolescent girls with rigorous designs, longer follow-ups, use of objective measures, and assessment of potential mediators of behaviour change. Moreover, studies would 
benefit from learning from those adolescent girls who are active and who enjoy being active. Qualitative work with such girls, as well as with those less motivated, could identify potential strategies to engage the adolescent girls who need interventions. Meanwhile, our results suggest that interventions might usefully target younger adolescent girls in girls-only school settings, using multi-component strategies and based on strong theory.

Funding: no direct funding was provided. 


\section{References}

1. Biddle SJH, Brehm W, Hopman-Rock M, et al. Population physical activity behaviour change: A review for the European College of Sport Science. Eur J Sport Sci. 2012;12:367-383.

2. Dumith SC, Gigante DP, Domingues MR, et al. Physical activity change during adolescence: A systematic review and pooled analysis. Int J Epidemiol. 2011;40:685698.

3. Telama R. Tracking of physical activity from childhood to adulthood: a review. Obes Facts 2009;2(3):187-95.

4. Stone EJ, McKenzie TL, Welk GJ, et al. Effects of physical activity interventions in youth. Review and synthesis. Am J Prev Med. 1998;15:298-315.

5. Ringuet CJ, Trost SG. Effects of physical activity intervention in youth: A review. Int Sports Med J. 2001;2:1-10.

6. van Sluijs EMF, McMinn AM, Griffin SJ. Effectiveness of interventions to promote physical activity in children and adolescents: Systematic review of controlled trials. BMJ. 2007;335:703.

7. Camacho-Minano MJ, LaVoi NM, Barr-Anderson DJ. Interventions to promote physical activity among young and adolescent girls: A systematic review. Health Educ Res. 2011;26:1025-1049.

8. Biddle SJ, Braithwaite R, Pearson N. The effectiveness of interventions to increase physical activity among young girls: a meta-analysis. Prev Med. 2014;62:119-31.

9. Brown AS. Promoting physical activity amongst adolescent girls. Issues Compr Pediatr Nurs. 2009;32:49-64. 
10. De Bourdeaudhuij I, Van Cauwenberghe E, Spittaels H, et al. School-based interventions promoting both physical activity and healthy eating in Europe: A systematic review within the HOPE project. Obes Rev. 2011;2:205-216.

11. De Meester F, van Lenthe F, Spittaels H, et al. Interventions for promoting physical activity among European teenagers: a systematic review. Int J Behav Nutr Phys Act. 2009;6:82.

12. DeMattia L, Lemont L, Meurer L. Do interventions to limit sedentary behaviours change behaviour and reduce childhood obesity? A critical review of the literature. Obes Rev. 2007;8:69-81.

13. Foley L, Maddison R. Use of active video games to increase physical activity in children: A (virtual) reality? Pediatr Exerc Sci. 2010;22:7-20.

14. Hamel LM, Robbins LB, Wilbur J. Computer- and web-based interventions to increase preadolescent and adolescent physical activity: A systematic review. J Adv Nurs. 2011;67:251-268.

15. Jago R, Baranowski T. Non-curricular approaches for increasing physical activity in youth: A review. Prev Med. 2004;39:157-163.

16. Lubans DR, Morgan PJ, Tudor-Locke C. A systematic review of studies using pedometers to promote physical activity among youth. Prev Med. 2009;48(4):307-15.

17. Ogilvie D, Foster CE, Rothnie H, et al. Interventions to promote walking: Systematic review. BMJ. 2007;334:1204.

18. Pate RR, O'Neill JR. After-school interventions to increase physical activity among youth. Br J Sports Med. 2009;43(1):14-8.

19. Salmon J, Booth ML, Phongsavan P, et al. Promoting physical activity participation among children and adolescents. Epidemiol Rev. 2007;29:144-159. 
20. Timperio A, Salmon J, Ball K. Evidence-based strategies to promote physical activity among children, adolescents and young adults: review and update. J Sci Med Sport. 2004;7(1 Suppl):20-9.

21. Ward DS, Vaughn A, McWilliams C, et al. Interventions for increasing physical activity at child care. Med Sci Sports Exerc. 2010;42:526-534.

22. Higgins JP, Altman DG, Gotzsche PC, et al. The Cochrane Collaboration's tool for assessing risk of bias in randomised trials. BMJ. 2011;343:d5928.

23. Greenhouse JB, Iyengar S. Sensitivity analysis and diagnostics. In: Cooper H, Hedges LV, eds. The handbook of research synthesis. New York: Russell Sage Foundation; 1994:383-398.

24. Begg CB. Publication bias. In: Cooper H, Hedges LV, eds. The handbook of research synthesis. New York: Russell Sage Foundation; 1994:400-408.

25. Rosenthal R. The 'file drawer problem' and the tolerance for null results. Psychol Bull. 1979;86:638-41.

26. Light RJ, Pillemer DB. Summing up the science of reviewing research. Cambridge, Massachusetts: Harvard University Press; 1984.

27. Duval S, Tweedie R. Trim and fill: A simple funnel-plot-based method of testing and adjusting for publication bias in meta-analysis. Biometrics. 2000;56(2):455-63.

28. Duval S, Tweedie R. A nonparametric "trim and fill" method of accounting for publication bias in meta-analysis. J Am Stat Assoc. 2000;95(449):89-98.

29. Borenstein M, Hedges LV, Higgins JP, et al. Comprehensive meta-analysis version 2. Englewood, NJ: Biostat; 2005

30. Borenstein M, Hedges LV, Higgins JP, et al. A basic introduction to fixed and random effects models for meta-analysis. Res Syn Meth. 2010;1:97-111. 
31. Matt GE, Cook TD. Threats to the validity of research synthesis. In: Cooper H, Hedges LV, eds. The handbook of research synthesis. New York: Russell Sage Foundation; 1994:503-520.

32. Cooper H. Synthesizing research: A guide for literature reviews. 3rd ed. Thousand Oaks, CA: Sage; 1998.

33. Hedges LB, Olkin I. Statistical methods for meta-analysis. Orlando, FL: Academic Press; 1985.

34. Field AP. Meta-analysis of correlation coefficients: A Monte Carlo comparison of fixedand random-effects methods. Psychol Methods. 2001;6(2):161-80.

35. Hedges LV, Vevea JL. Fixed and random effects models in meta-analysis. Psychol Methods. 1998;3:486-504.

36. Field AP. Can meta-analysis be trusted? Psychologist. 2003;16(12):642-45.

37. Field AP. Is the meta-analysis of correlation coefficients accurate when population correlations vary? Psychol Methods. 2005;10(4):444-67.

38. Shadish WR, Sweeney RB. Mediators and moderators in meta-analysis: There's a reason we don’t let dodo birds tell us which psychotherapies should have prizes. J Consult Clin Psych. 1991;59:883-893.

39. Borenstein M, Hedges LV, Higgins JP, et al. Introduction to meta-analysis. Chichester, UK: Wiley; 2009.

40. Higgins JPT, Thompson SG, Deeks JJ, et al. Measuring inconsistency in meta-analyses. Brit Med J. 2003;327:557-560.

41. Slootmaker SM, Chinapaw MJ, Seidell JC, et al. Accelerometers and Internet for physical activity promotion in youth? Feasibility and effectiveness of a minimal intervention. Prev Med. 2010;51:31-36. 
42. Prochaska JJ, Sallis JF. A randomized controlled trial of single versus multiple health behavior change: promoting physical activity and nutrition among adolescents. Health Psychol. 2004;23:314-318.

43. DeBar LL, Ritenbaugh C, Aickin M, et al. Youth: a health plan-based lifestyle intervention increases bone mineral density in adolescent girls. Arch Pediatr Adolesc Med. 2006;160:1269-1276.

44. Cohen J. Statistical power analysis for the behavioral sciences. Hillsdale, NJ: Erlbaum; 1988.

45. Pate RR, Ward DS, Saunders RP, et al. Promotion of physical activity among high-school girls: A randomized controlled trial. Am J Public Health. 2005; 95:1582-1587.

46. Dishman RK, Motl RW, Saunders R, et al. Self-efficacy partially mediates the effect of a school-based physical-activity intervention among adolescent girls. Prev Med. 2004;38:628-636.

47. Dishman RK, Motl RW, Saunders R, et al. Enjoyment mediates effects of a school-based physical-activity intervention. Med Sci Sports Exerc. 2005;37:478-487.

48. Jones D, Hoelscher DM, Kelder SH, et al. Increasing physical activity and decreasing sedentary activity in adolescent girls - The Incorporating More Physical Activity and Calcium in Teens (IMPACT) study. Int J Behav Nutr Phys Act. 2008;5:42-52.

49. Heath GW, Parra DC, Sarmiento OL, et al. Evidence-based intervention in physical activity: lessons from around the world. Lancet. 2012;380:272-281.

50. Beets MW, Beighle A, Erwin HE, et al. After-school program impact on physical activity and fitness: A meta-analysis. Am J Prev Med. 2009;36:527-537.

51. Bartholomew LK, Parcel GS, Kok G, et al. Planning health promotion programs: An intervention mapping approach. 2nd ed. San Francisco, CA: John Wiley; 2006. 
52. Bandura A. Social foundations of thought and action: A social cognitive theory. Englewood Cliffs, NJ: Prentice Hall; 1986.

53. Whitehead S, Biddle SJH. Adolescent girls' perceptions of physical activity: A focus group study. Eur Phys Educ Rev. 2008;14:243-62.

54. Bayne-Smith M, Fardy PS, Azzollini A, et al. Improvements in heart health behaviors and reduction in coronary artery disease risk factors in urban teenaged girls through a school-based intervention: the PATH program. Am J Public Health. 2004;94:15381543.

55. Bronikowski M. Is sense of coherence needed to keep youth physically active? Medicina Dello Sport. 2010;63(4):465-83.

56. Bronikowski M, Bronikowska M. Will they stay fit and healthy? A three-year follow-up evaluation of a physical activity and health intervention in Polish youth. Scand $J$ Public Health. 2011;39(7):704-13.

57. Bush LP, Laberge S, Laforest S. Physical activity promotion among underserved adolescents: "make it fun, easy, and popular". Health Promot Pract. 2010;11(3 Suppl):79S-87S.

58. Chin A Paw M, Singh AS, Brug J, et al. Why did soft drink consumption decrease but screen time not? Mediating mechanisms in a school-based obesity prevention program. Int J Behav Nutr Phys Act. 2008;5:41.

59. Singh AS, Chin APMJ, Brug J, et al. Dutch obesity intervention in teenagers: effectiveness of a school-based program on body composition and behavior. Arch Pediatr Adolesc Med. 2009;163:309-317.

60. DeBar LL, Stevens VJ, Perrin N, et al. A primary care-based, multicomponent lifestyle intervention for overweight adolescent females. Pediatrics. 2012;3:e611-620. 
61. Dewar DL, Morgan PJ, Plotnikoff RC, et al. Exploring changes in physical activity, sedentary behaviors and hypothesized mediators in the NEAT girls group randomized controlled trial. J Sci Med Sport. 2013;Mar 15:pii: S1440-2440(13)00035-2. doi:

10.1016/j.jsams.2013.02.003. [Epub ahead of print]

62. Dudley DA, Okely AD, Pearson P, et al. Engaging adolescent girls from linguistically diverse and low income backgrounds in school sport: A pilot randomised controlled trial. J Sci Med Sport. 2010;13:217-224.

63. Dunton GF, Schneider M, Cooper DM. An investigation of psychosocial factors related to changes in physical activity and fitness among female adolescents. Psychol Health. 2007;22:929-944.

64. Everhart B, Harshaw C, Everhart B, et al. Multimedia software's effects on high school physical education students' fitness patterns. Phys Educat. 2002;59:151-157.

65. Fairclough S, Stratton G. Improving health-enhancing physical activity in girls' physical education. Health Educ Res. 2005;20(4):448-57.

66. Fairclough S, Stratton G. Effects of a physical education intervention to improve student activity levels. Phys Educ Sport Pedagogy. 2006;11:29-44.

67. Gortmaker SL, Peterson K, Wiecha J, et al. Reducing obesity via a school-based interdisciplinary intervention among youth - Planet health. Arch Pediatr Adolesc Med. 1999;153:409-418.

68. Haerens L, Deforche B, Maes L, et al. Evaluation of a 2-year physical activity and healthy eating intervention in middle school children. Health Educ Res. 2006;6:911921. 
69. Jago R, Sebire SJ, Cooper AR, Haase AM, Powell J, Davis L, et al. Bristol girls dance project feasibility trial: outcome and process evaluation results. Int J Behav Nutr Phys Act. 2012;9:83.

70. Jamner MS, Spruijt-Metz D, Bassin S, et al. A controlled evaluation of a school-based intervention to promote physical activity among sedentary adolescent females: Project FAB. J Adolesc Health. 2004;34:279-289.

71. Graham DJ, Schneider M, Cooper DM. Television viewing: moderator or mediator of an adolescent physical activity intervention? Am J Health Promot. 2008;23(2):88-91.

72. Schneider M, Dunton GF, Bassin S, et al. Impact of a school-based physical activity intervention on fitness and bone in adolescent females. Phys Act Health. 2007;4:1-13.

73. Schneider M, Dunton GF, Cooper DM. Physical activity and physical self-concept among sedentary adolescent females: An intervention study. Psychol Sport Exerc. 2008;9:14.

74. Schneider M, Cooper DM. Enjoyment of exercise moderates the impact of a school-based physical activity intervention. Int J Behav Nutr Phys Act. 2011;8:64.

75. Kelder SH, Perry CL, Klepp KI. Community-wide youth exercise promotion: Long-term outcomes of the Minnesota Heart Health Program and the Class of 1989 Study. J Sch Health. 1993;63:218-223.

76. Perry CL, Kelder SH, Klepp KI. Community-wide cardiovascular disease prevention in young people. Eur J Public Health. 1994;4:188-194.

77. Killen JD, Telch MJ, Robinson TN, et al. Cardiovascular disease risk reduction for tenth graders. A multiple-factor school-based approach. JAMA. 1988;260:1728-1733.

78. Killen JD, Robinson TN, Telch MJ, et al. The Stanford Adolescent Heart Health Program. Health Educ Q. 1989;16:263-283. 
79. Lubans DR, Sylva K. Mediators of change following a senior school physical activity intervention. J Sci Med Sport. 2009;12(1):134-40.

80. Sallis JF, McKenzie TL, Conway TL, et al. Environmental interventions for eating and physical activity: A randomized controlled trial in middle schools. Am J Prev Med. 2003;24:209-17.

81. McKenzie TL, Sallis JF, Prochaska JJ, et al. Evaluation of a two-year middle-school physical education intervention: M-SPAN. Med Sci Sports Exerc. 2004;36:13821388.

82. Nader PR, Sallis JF, Abramson IS, et al. Family-based cardiovascular risk reduction education among Mexican and Anglo-Americans. Fam Community Health. 1992;15:57-58.

83. Neumark-Sztainer D, Story M, Hannan PJ, et al. New Moves: a school-based obesity prevention program for adolescent girls. Prev Med. 2003;37:41-51.

84. Neumark-Sztainer DR, Friend SE, Flattum CF, et al. New moves-preventing weightrelated problems in adolescent girls a group-randomized study. Am J Prev Med. 2010;39:421-432.

85. Patrick K, Calfas KJ, Norman GJ, et al. Randomized controlled trial of a primary care and home-based intervention for physical activity and nutrition behaviors: PACE+ for adolescents. Arch Pediatr Adolesc Med. 2006;160(2):128-136.

86. Perry CL, Klepp K-I, Halper A, et al. Promoting healthy eating and physical activity patterns among adolescents: a pilot study of 'Slice of Life'. Health Educ Res. 1987;2:93-103.

87. Robbins LB, Gretebeck KA, Kazanis AS, et al. Girls on the move program to increase physical activity participation. Nurs Res. 2006;55:206-216. 
88. Robbins LB, Pfeiffer KA, Maier KS, et al. Pilot intervention to increase physical activity among sedentary urban middle school girls: A two-group pretest-posttest quasiexperimental design. $J$ Sch Nurs. 2012;28:302-315.

89. Schofield L, Mummery WK, Schofield G. Effects of a controlled pedometer-intervention trial for low-active adolescent girls. Med Sci Sports Exerc. 2005;37:1414-1420.

90. Simon C, Wagner A, DiVita C, et al. Intervention centred on adolescents' physical activity and sedentary behaviour (ICAPS): Concept and 6-month results. Int J Obes. 2004;28:s96-s103.

91. Spruijt-Metz D, Nguyen-Michel ST, Goran MI, et al. Reducing sedentary behavior in minority girls via a theory-based, tailored classroom media intervention. Int J Pediatr Obes. 2008;3:240-248.

92. Taymoori P, Niknami S, Berry T, et al. A school-based randomized controlled trial to improve physical activity among Iranian high school girls. Int J Behav Nutr Phys Act. 2008;5:18.

93. Young DR, Phillips JA, Yu T, et al. Effects of a life skills intervention for increasing physical activity in adolescent girls. Arch Pediatr Adolesc Med. 2006;12:1255-1261.

94. Winett RA, Roodman AA, Winett SG, et al. The effects of the Eat4Life Internet-based health behavior program on the nutrition and activity practices of high school girls. J Gender Culture Health. 1999;3:239-254. 
Table 1. Intervention characteristics of included studies aiming to increase physical activity among adolescent girls $(\mathrm{k}=34)$

\begin{tabular}{|c|c|c|c|c|}
\hline $\begin{array}{l}\text { Author (year), } \\
\text { country }\end{array}$ & $\begin{array}{l}\text { Intervention } \\
\text { name }\end{array}$ & Design & Participants & Description of intervention and control conditions \\
\hline $\begin{array}{l}\text { Bayne-Smith et al., } \\
2004^{54} \text { US }\end{array}$ & $\begin{array}{l}\text { PATH } \\
\text { programme }\end{array}$ & $\begin{array}{l}\text { Randomised } \\
\text { controlled trial } \\
\text { (individual and } \\
\text { class) }\end{array}$ & $\begin{array}{l}\mathrm{N}=442 \text { girls. } \\
\text { Mean age } 16.0 \\
\text { (SD 1.3) years }\end{array}$ & $\begin{array}{l}\text { Intervention group: } 12 \text { week, physical education curriculum based } \\
\text { programme. Daily } 30 \text { minute classes (five days per week); classes } \\
\text { consisted of 5-10minute lecture and } 20-25 \text { minutes of vigorous } \\
\text { physical activity, with additional homework assignments. Control } \\
\text { group: normal curriculum (no lecture, so about } 5 \text { minutes more } \\
\text { physical activity per class). }\end{array}$ \\
\hline
\end{tabular}


Table 1. Intervention characteristics of included studies aiming to increase physical activity among adolescent girls ( $\mathrm{k}=34)($ Cont'd/..)

\begin{tabular}{|l|l|l|l|l|}
\hline $\begin{array}{l}\text { Author (year), } \\
\text { country }\end{array}$ & $\begin{array}{l}\text { Intervention } \\
\text { name }\end{array}$ & Design & Participants & Description of intervention and control conditions \\
\hline $\begin{array}{l}\text { Bush et al., 2010 } \\
\text { Canada }\end{array}$ & $\begin{array}{l}\text { FunAction } \\
\text { programme }\end{array}$ & $\begin{array}{l}\text { Quasi- } \\
\text { experimental } \\
\text { (year group) }\end{array}$ & $\begin{array}{l}\text { N=131 girls aged } \\
11-15 \text { years. }\end{array}$ & $\begin{array}{l}\text { Intervention group: 16 week intervention led by university } \\
\text { students. Up to 3 different activities per day were offered 3-5 } \\
\text { days a week during lunch time for 45 minutes (non-curricular } \\
\text { intervention). Control group usual lunch time. }\end{array}$ \\
\hline $\begin{array}{l}\text { Chin A Paw et al., } \\
\text { 2008 }{ }^{58} 59 \\
\text { Netherlands }\end{array}$ & DoiT & $\begin{array}{l}\text { Cluster } \\
\text { Randomised } \\
\text { Controlled } \\
\text { Trial (school) }\end{array}$ & $\begin{array}{l}\text { N=436 girls. } \\
\text { Mean age 12.6 } \\
\text { (SD 0.4) years }\end{array}$ & $\begin{array}{l}\text { Intervention included an individual and an environmental } \\
\text { component. Individual component consisted of an educational } \\
\text { programme covering 11 lessons for the subjects biology and PE. } \\
\text { Environmental component involved encouraging additional } \\
\text { changes to PE classes and school cafeteria. Control schools were } \\
\text { requested to maintain usual practice. }\end{array}$ \\
\hline $\begin{array}{l}\text { DeBar et al. 2012 } \\
\text { US }\end{array}$ & No name & $\begin{array}{l}\text { Randomised } \\
\text { Controlled } \\
\text { Trial } \\
\text { (individual) }\end{array}$ & $\begin{array}{l}\text { N=208 girls. } \\
\text { Mean age 14.1 } \\
\text { (SD 1.4) years. }\end{array}$ & $\begin{array}{l}\text { Multicomponent intervention comprised sixteen 90 minute group } \\
\text { meetings over 5 months. The multicomponent intervention } \\
\text { included the following: (1) change in dietary intake and eating } \\
\text { patterns; (2) increasing physical activity by using } \\
\text { developmentally tailored forms of exercise (eg, exergaming); (3) } \\
\text { addressing issues associated with obesity in adolescent girls (e.g. } \\
\text { depression, disordered eating patterns, poor body image); and (4) } \\
\text { training participants' primary care providers to support } \\
\text { behavioural weight management goals collaboratively. Group } \\
\text { sessions were also held for parents so that they could support } \\
\text { their daughters. Control group: usual practice. }\end{array}$ \\
\hline
\end{tabular}


Table 1. Intervention characteristics of included studies aiming to increase physical activity among adolescent girls ( $\mathrm{k}=34)($ Cont'd/..)

\begin{tabular}{|c|c|c|c|c|}
\hline $\begin{array}{l}\text { Author (year), } \\
\text { country }\end{array}$ & $\begin{array}{l}\text { Intervention } \\
\text { name }\end{array}$ & Design & Participants & Description of intervention and control conditions \\
\hline $\begin{array}{l}\text { Dewar et al. } 2013^{61} \\
\text { Australia }\end{array}$ & NEAT Girls & $\begin{array}{l}\text { Randomised } \\
\text { Controlled } \\
\text { Trial (School) }\end{array}$ & & $\begin{array}{l}\text { The } 12 \text { month intervention included enhanced school sport, } \\
\text { lunchtime physical activity sessions, interactive seminars, student } \\
\text { handbooks, nutrition workshops, pedometers, parent newsletters } \\
\text { and text messages to encourage physical activity and healthy } \\
\text { eating, and a decrease in sedentary behavior. Control group: usua } \\
\text { practice. }\end{array}$ \\
\hline
\end{tabular}


Table 1. Intervention characteristics of included studies aiming to increase physical activity among adolescent girls ( $\mathrm{k}=34)($ Cont'd/..)

\begin{tabular}{|c|c|c|c|c|}
\hline $\begin{array}{l}\text { Author (year), } \\
\text { country }\end{array}$ & $\begin{array}{l}\text { Intervention } \\
\text { name }\end{array}$ & Design & Participants & Description of intervention and control conditions \\
\hline $\begin{array}{l}\text { Dunton et al., } 2007^{63} \\
\text { US }\end{array}$ & No name & $\begin{array}{l}\text { Controlled trial } \\
\text { (School) }\end{array}$ & $\begin{array}{l}\mathrm{N}=146 \text { girls. } \\
\text { Mean } 15.10 \text { (SD } \\
0.81 \text { ) years. }\end{array}$ & $\begin{array}{l}\text { The intervention class met five days a week for } 60 \text { minutes each } \\
\text { day (approx. } 40 \text { minutes of activity), with one day a week } \\
\text { devoted to an educational component. Class activities included } \\
\text { yoga, aerobics, swimming, weight-training, dance etc. Weekly } \\
\text { lectures addressed topics such as time management, body image, } \\
\text { motivation, nutrition, and strength training. } \\
\text { Control schools received no intervention. }\end{array}$ \\
\hline $\begin{array}{l}\text { Everhart et al., } \\
2003^{64} \text { US }\end{array}$ & No name & $\begin{array}{l}\text { Controlled trial } \\
\text { (individual) }\end{array}$ & $\begin{array}{l}\mathrm{N}=78 \text { girls (high } \\
\text { school aged) }\end{array}$ & $\begin{array}{l}\text { Students in intervention group interacted with a multimedia } \\
\text { software programme designed to provide nutritional information } \\
\text { and record workout and nutritional patterns. Students entered } \\
\text { their physical activity participation and eating behaviours into the } \\
\text { programme. Control students took part in usual PE and had no } \\
\text { access to the multimedia programme. }\end{array}$ \\
\hline $\begin{array}{l}\text { Gortmaker et al., } \\
1999^{67} \text { US }\end{array}$ & Planet Health & $\begin{array}{l}\text { Randomised } \\
\text { controlled trial } \\
\text { (school) }\end{array}$ & $\begin{array}{l}\mathrm{N}=627 \text { girls. } \\
\text { Mean age } 11.6 \\
\text { (SD 0.6) years. }\end{array}$ & $\begin{array}{l}\text { Intervention group: } 2 \text { year programme, } 32 \text { classroom based } \\
\text { sessions taught by regular teachers (who received training from } \\
\text { planet health staff). Interdisciplinary intervention for prevention } \\
\text { of obesity aimed at decreasing TV viewing, making space for } \\
\text { activity, healthy eating, with a focus on 'lifestyle' changes in } \\
\text { behaviour. Control group: usual curriculum. }\end{array}$ \\
\hline
\end{tabular}


Table 1. Intervention characteristics of included studies aiming to increase physical activity among adolescent girls ( $\mathrm{k}=34)($ Cont'd/..)

\begin{tabular}{|c|c|c|c|c|}
\hline $\begin{array}{l}\text { Author (year), } \\
\text { country }\end{array}$ & $\begin{array}{l}\text { Intervention } \\
\text { name }\end{array}$ & Design & Participants & Description of intervention and control conditions \\
\hline $\begin{array}{l}\text { Haerens et al., } \\
2006^{68} \text { Belgium }\end{array}$ & No name & $\begin{array}{l}\text { Randomised } \\
\text { controlled trial } \\
\text { (school) }\end{array}$ & $\begin{array}{l}\mathrm{N}=1039 \text { girls. } \\
\text { Mean age } 13.1 \\
\text { (SD 0.8) years. }\end{array}$ & $\begin{array}{l}\text { Intervention group 1: } 2 \text { year intervention implemented by school } \\
\text { staff. Focus on creating opportunities for physical activity during } \\
\text { breaks, lunch, and after school. Provision of extra sports material } \\
\text { and setting up of variety of (non-competitive) activities. } \\
\text { Computer tailored intervention (once in year 2) providing } \\
\text { feedback on physical activity levels and determinants. } \\
\text { Intervention group 2: intervention group } 1 \text { plus parents invited to } \\
\text { interactive meeting on physical activity, diet, and health. Parents } \\
\text { received CD with similar computer tailored intervention and } \\
\text { regular newsletters. Control group: usual curriculum }\end{array}$ \\
\hline $\begin{array}{l}\text { Jago et al. } 2010^{69} \\
\text { UK }\end{array}$ & $\begin{array}{l}\text { Bristol Girls } \\
\text { Dance } \\
\text { Project } \\
\text { (BGDP) }\end{array}$ & $\begin{array}{l}\text { Cluster } \\
\text { Randomised } \\
\text { Controlled } \\
\text { Trial (school) }\end{array}$ & $\begin{array}{l}\mathrm{N}=203 \text { girls aged } \\
11-12 \text { years. }\end{array}$ & $\begin{array}{l}\text { Intervention schools received two, 90-minute after-school dance } \\
\text { classes per week for } 9 \text { weeks. The dance class content included } \\
\text { opportunities for participant input and time to practice short } \\
\text { dance pieces. All sessions were based on the hip-hop/street dance } \\
\text { genre. At the end of the intervention all participants were } \\
\text { provided with information about local dance opportunities. } \\
\text { Instructors were provided with the outline dance program and } \\
\text { attended a half-day content familiarization session. } \\
\text { "Control incentives only" group received small thank you gifts of } \\
£ 3, £ 5 \text { and } £ 10 \text { for data collections } 1,2 \text { and } 3 \text { respectively. } \\
\text { "Control incentives + workshop" were provided with the same } \\
\text { small thank you gifts as well as a half-day dance workshop at the } \\
\text { end of the study. }\end{array}$ \\
\hline
\end{tabular}


Table 1. Intervention characteristics of included studies aiming to increase physical activity among adolescent girls (k=34) (Cont'd/..)

\begin{tabular}{|l|l|l|l|l|}
\hline $\begin{array}{l}\text { Author (year), } \\
\text { country }\end{array}$ & $\begin{array}{l}\text { Intervention } \\
\text { name }\end{array}$ & Design & Participants & Description of intervention and control conditions \\
\hline $\begin{array}{l}\text { Jamner et al., } 2004 \\
\text { J0 }\end{array}$ & Project FAB & $\begin{array}{l}\text { Controlled trial } \\
\text { (school) }\end{array}$ & $\begin{array}{l}\text { N=122 girls. } \\
\text { Mean age 15.04 } \\
\text { (SD 0.79) years }\end{array}$ & $\begin{array}{l}\text { The intervention goal was to increase students levels of PA } \\
\text { through supervised in-class activity, health education, and } \\
\text { internet-based self-monitoring. Participants in the intervention } \\
\text { school attended supervised exercise sessions 4 days a week over 4 } \\
\text { months of a school year (40 minutes of PA per session). Health } \\
\text { education was provided during class on the fifth day. The } \\
\text { supervised PA sessions were in part determined by participant } \\
\text { preferences. }\end{array}$ \\
Control school were given no instruction regarding PA, usual PE \\
curriculum.
\end{tabular}


Table 1. Intervention characteristics of included studies aiming to increase physical activity among adolescent girls ( $\mathrm{k}=34)($ Cont'd/..)

\begin{tabular}{|c|c|c|c|c|}
\hline $\begin{array}{l}\text { Author (year), } \\
\text { country }\end{array}$ & $\begin{array}{l}\text { Intervention } \\
\text { name }\end{array}$ & Design & Participants & Description of intervention and control conditions \\
\hline $\begin{array}{l}\text { Jones et al., } 2008^{48} \\
\text { US }\end{array}$ & IMPACT & $\begin{array}{l}\text { Randomised } \\
\text { controlled trial } \\
\text { (school) }\end{array}$ & $\begin{array}{l}\mathrm{N}=718 \text { girls. } \\
\text { Mean age } 11.6 \\
\text { (SD 0.4) years. }\end{array}$ & $\begin{array}{l}\text { IMPACT intervention sought to affect behaviour change through } \\
\text { promoting active learning in classrooms as well as through } \\
\text { environmental reinforcement. To this end, the intervention } \\
\text { consisted of three major components: a health curriculum for } \\
\text { grades } 6 \text { and } 7 \text { which included classroom lessons and behavioural } \\
\text { journalism, a physical education program, and a school food } \\
\text { service component that emphasized calcium rich food choices. } \\
\text { The use of peer-based behavioural journalism involved the use of } \\
\text { media such as a school-based newsletter with role model stories } \\
\text { to increase adoption of desired behaviours. The over-arching goal } \\
\text { of the physical activity component of the IMPACT trial was to } \\
\text { improve bone health in the study sample by increasing overall } \\
\text { levels of physical activity, specifically focusing on increasing } \\
\text { weight bearing physical activity. To this end, the intervention } \\
\text { employed a 6th grade health curriculum which included } 16 \\
\text { sessions that were implemented during physical education classes } \\
\text { (3 times/week). The lessons in this curriculum were designed to } \\
\text { promote increased consumption of calcium-rich foods and } \\
\text { increased activity, specifically weight-bearing physical activities, } \\
\text { while participating in behaviourally-based and active lessons } \\
\text { adapted to the physical education environment. During 7th grade, } \\
\text { a series of science-based lessons were administered during } \\
\text { science classes. The physical education component of the } \\
\text { program known as IMPACTivities, was implemented in the 6th } \\
\text { and } 7 \text { th grades during physical education (PE) and athletics } \\
\text { classes. The PE classes focused on an initial } 10 \text { minute warm-up } \\
\text { (range: } 5 \text {-15 minutes), which consisted of high impact activities } \\
\text { such as rope-jumping, circuit training and box-step activities. }\end{array}$ \\
\hline
\end{tabular}


Table 1. Intervention characteristics of included studies aiming to increase physical activity among adolescent girls ( $\mathrm{k}=34)($ Cont'd/..)

\begin{tabular}{|l|l|l|l|l|}
\hline $\begin{array}{l}\text { Author (year), } \\
\text { country }\end{array}$ & $\begin{array}{l}\text { Intervention } \\
\text { name }\end{array}$ & Design & Participants & Description of intervention and control conditions \\
\hline $\begin{array}{l}\text { Kelder et al., 1993 } \\
76\end{array}$ & $\begin{array}{l}\text { Class of } 1989 \\
\text { study }\end{array}$ & $\begin{array}{l}\text { Controlled trial } \\
\text { (class) }\end{array}$ & $\begin{array}{l}\mathrm{N}=1196 \text { girls } \\
\text { aged 13-14 years. }\end{array}$ & $\begin{array}{l}\text { Intervention group: received the MHHP intervention plus the } \\
\text { class of 1989 intervention: classroom based intervention using } \\
\text { peer leaders; self-monitoring intervention FM250 in 8th grade } \\
\text { (hypothetically cycle 250 miles between two towns in 4 weeks, } \\
\text { based on daily energy expenditure). In 10th grade the 'slice of life } \\
\text { programme' was implemented. A 7 session programme focused } \\
\text { on skills to improve eating and exercise patterns. Control group: } \\
\text { no intervention }\end{array}$ \\
\hline $\begin{array}{l}\text { Killen et al., 1988- } \\
89^{77} \text { 78 US }\end{array}$ & $\begin{array}{l}\text { Stanford } \\
\text { Adolescent } \\
\text { Heart Health } \\
\text { Programme }\end{array}$ & $\begin{array}{l}\text { Randomised } \\
\text { controlled trial } \\
\text { (school) }\end{array}$ & $\begin{array}{l}\text { N=518 girls aged } \\
14-16 \text { years. }\end{array}$ & $\begin{array}{l}\text { Intervention group: 7 week classroom based educational } \\
\text { programme (three 50 minute sessions per week) taught by special } \\
\text { teachers in five modules (physical education, diet, smoking, } \\
\text { stress, problem solving). Each module contained health benefits, } \\
\text { skills acquisition, resisting social influence, and skills practice. } \\
\text { Control group: usual curriculum }\end{array}$ \\
\hline $\begin{array}{l}\text { Lubans \& Sylva, } \\
2009^{79} \text { UK }\end{array}$ & LAP & $\begin{array}{l}\text { Randomised } \\
\text { controlled trial } \\
\text { (individual) }\end{array}$ & $\begin{array}{l}\text { N=48 girls aged } \\
16-18 \text { years. }\end{array}$ & $\begin{array}{l}\text { Intervention: group met twice a week for 10-weeks. One session } \\
\text { involved a researcher-led work-out, for the other session, students } \\
\text { completed their own training. The LAP was a conceptual PE } \\
\text { program developed with reference to SCT and SET. Control } \\
\text { group: required to attend the same health centre and complete } \\
\text { their own activity for two 90 minute sessions per week. }\end{array}$ \\
\hline
\end{tabular}


Table 1. Intervention characteristics of included studies aiming to increase physical activity among adolescent girls ( $\mathrm{k}=34)($ Cont'd/..)

\begin{tabular}{|c|c|c|c|c|}
\hline $\begin{array}{l}\text { Author (year), } \\
\text { country }\end{array}$ & $\begin{array}{l}\text { Intervention } \\
\text { name }\end{array}$ & Design & Participants & Description of intervention and control conditions \\
\hline $\begin{array}{l}\text { Sallis et al., } 2003^{80} \\
{ }^{81} \text { US }\end{array}$ & M-SPAN & $\begin{array}{l}\text { Randomised } \\
\text { controlled trial } \\
\text { (school) }\end{array}$ & $\begin{array}{l}\mathrm{N}=24 \text { classes of } \\
\text { girls aged } 11-13 \\
\text { years. }\end{array}$ & $\begin{array}{l}\text { Intervention group: } 2 \text { year programme based on ecological model } \\
\text { focused on physical activity and nutrition. Physical activity } \\
\text { intervention included changing content and structure of physical } \\
\text { education, increasing choice for physical activity during leisure } \\
\text { periods and environmental changes (increased supervision, } \\
\text { equipment, and activities). No health promotion. Control group: } \\
\text { usual curriculum. (schools received } \$ 1000 \text { (£500; €700) for } \\
\text { physical education equipment) }\end{array}$ \\
\hline $\begin{array}{l}\text { Nader et al., } 1992^{82} \\
\text { US }\end{array}$ & No name & $\begin{array}{l}\text { Randomised } \\
\text { controlled trial } \\
\text { (school) }\end{array}$ & $\begin{array}{l}\mathrm{N}=158 \text { girls. } \\
\text { Mean ages ranged } \\
\text { from } 11.8-12.1 \\
\text { years. }\end{array}$ & $\begin{array}{l}\text { Intervention group: 12-week intensive intervention consisting of } \\
12 \text { after school sessions ( } 90 \text { minutes), with family attendance. } \\
\text { Each session included aerobic exercise, education (separate for } \\
\text { children and adults), behaviour management, and heart healthy } \\
\text { snacks. This was followed by six maintenance sessions over the } \\
\text { following } 9 \text { months. Control group: no intervention. Four groups } \\
\text { in total, Intervention Anglo-American and Mexican-American, } \\
\text { and control Anglo-American and Mexican-American. }\end{array}$ \\
\hline $\begin{array}{l}\text { Neumark-Sztainer et } \\
\text { al., } 2003^{83} \text { US }\end{array}$ & New Moves & $\begin{array}{l}\text { Randomised } \\
\text { controlled trial } \\
\text { (school) }\end{array}$ & $\begin{array}{l}\mathrm{N}=201 \text { girls. } \\
\text { Mean age } 15.4 \\
\text { (SD 1.1) years. }\end{array}$ & $\begin{array}{l}\text { Intervention group: } 16 \text { week programme with five classes per } \\
\text { week. Female only PE classes four times a week and one } \\
\text { educational session per week (either discussion social support or } \\
\text { nutrition). Aimed to create environment in which larger girls } \\
\text { could feel comfortable being physically active. Control group: } \\
\text { girl's only PE usual curriculum. }\end{array}$ \\
\hline
\end{tabular}


Table 1. Intervention characteristics of included studies aiming to increase physical activity among adolescent girls ( $\mathrm{k}=34)($ Cont'd/..)

\begin{tabular}{|l|l|l|l|l|}
\hline $\begin{array}{l}\text { Author (year), } \\
\text { country }\end{array}$ & $\begin{array}{l}\text { Intervention } \\
\text { name }\end{array}$ & Design & Participants & Description of intervention and control conditions \\
\hline $\begin{array}{l}\text { Neumark-Sztainer et } \\
\text { al., } 2010^{84} \text { US }\end{array}$ & New Moves & $\begin{array}{l}\text { Randomised } \\
\text { controlled trial } \\
\text { (school) }\end{array}$ & $\begin{array}{l}\text { N=356 girls. } \\
\text { Mean age 15.8 } \\
\text { (SD 1.17) years. }\end{array}$ & $\begin{array}{l}\text { Intervention group: 16 week programme with five classes per } \\
\text { week. Female only PE classes four times a week and one } \\
\text { educational session per week (either discussion social support or } \\
\text { nutrition). Aimed to create environment in which larger girls } \\
\text { could feel comfortable being physically active. Control group: } \\
\text { girl's only PE usual curriculum. }\end{array}$ \\
\hline $\begin{array}{l}\text { Patrick et al, 2006 } \\
\text { US }\end{array}$ & $\begin{array}{l}\text { PACE+ for } \\
\text { adolescents }\end{array}$ & $\begin{array}{l}\text { Randomised } \\
\text { controlled trial } \\
\text { (individual) }\end{array}$ & $\begin{array}{l}\text { N=438 girls. } \\
\text { Mean age 12.7 } \\
\text { (SD 1.3) years. }\end{array}$ & $\begin{array}{l}\text { Intervention group: 12 month programme, one stage based } \\
\text { computer tailored intervention with endorsement of primary care } \\
\text { provider. Focus on diet and physical activity (MVPA and } \\
\text { sedentary behaviour). After initial consultation, participants } \\
\text { received manual and 11 telephone-based follow-up sessions. } \\
\text { Parents were targeted to help them encourage attempts at } \\
\text { behaviour change. Control group: sun protection intervention. }\end{array}$ \\
\hline $\begin{array}{l}\text { Perry et al., 1987 } \\
\text { US }\end{array}$ & Slice of Life & $\begin{array}{l}\text { Randomised } \\
\text { controlled trial } \\
\text { (class) }\end{array}$ & $\begin{array}{l}\text { N=159 girls aged } \\
14-15 \text { years. }\end{array}$ & $\begin{array}{l}\text { Intervention group: 10 sessions of peer led classroom based } \\
\text { educational intervention with focus on changing environmental, } \\
\text { personality, and behavioural attributes to behaviour change } \\
\text { (including videotaped instructions and goal setting, self- } \\
\text { monitoring, social support, and how to change environment). } \\
\text { Control group: usual curriculum. }\end{array}$ \\
\hline
\end{tabular}


Table 1. Intervention characteristics of included studies aiming to increase physical activity among adolescent girls ( $\mathrm{k}=34)($ Cont'd/..)

\begin{tabular}{|c|c|c|c|c|}
\hline $\begin{array}{l}\text { Author (year), } \\
\text { country }\end{array}$ & $\begin{array}{l}\text { Intervention } \\
\text { name }\end{array}$ & Design & Participants & Description of intervention and control conditions \\
\hline $\begin{array}{l}\text { Robbins et al., } \\
2006^{87} \text { US }\end{array}$ & $\begin{array}{l}\text { Girls on the } \\
\text { move }\end{array}$ & $\begin{array}{l}\text { Randomised } \\
\text { controlled trial } \\
\text { (grade) }\end{array}$ & $\begin{array}{l}\mathrm{N}=77 \text { girls aged } \\
11-13 \text { years }\end{array}$ & $\begin{array}{l}\text { Intervention group: } 9 \text { week programme set in school wellness } \\
\text { centre. Included three individually tailored computer sessions } \\
\text { with face to face feedback from school paediatric nurse, and two } \\
\text { telephone calls with research assistant, focusing on agreed goals. } \\
\text { Parents were posted tip sheets to support girls to achieve goals. } \\
\text { Control group: one page leaflet with age specific } \\
\text { recommendations for physical activity. }\end{array}$ \\
\hline $\begin{array}{l}\text { Robbins et al. } \\
2012^{88} \text { US }\end{array}$ & No name & $\begin{array}{l}\text { Quasi- } \\
\text { experimental } \\
\text { (school) }\end{array}$ & $\begin{array}{l}\mathrm{N}=69 \text { girls in } \\
\text { sixth and seventh } \\
\text { grade. }\end{array}$ & $\begin{array}{l}\text { The intervention involved two components: (1) a 90-min after- } \\
\text { school physical activity club offered at the middle school } 5 \text { days a } \\
\text { week for } 6 \text { months (total of } 98 \text { sessions) and (2) a face-to-face } \\
\text { motivational, individually tailored counselling session with a } \\
\text { registered (school) nurse during the school day every other month } \\
\text { over the } 6 \text { months (total of three } 20 \text {-min sessions were planned). } \\
\text { The attention control condition involved two components: (1) a } \\
\text { 90-min after-school workshop once a month for } 6 \text { months (total } \\
\text { of six workshops) and (2) a face-to-face session with a registered } \\
\text { (school) nurse during the school day every other month over the } 6 \\
\text { months (total of three } 20 \text {-min sessions were planned). Each } \\
\text { workshop focused on one of the following health-promoting } \\
\text { topics: (1) caring for my body; (2) fashion, hair, and nail tips; (3) } \\
\text { sun and food safety; (4) healthy relationships and friendship; (5) } \\
\text { building self-esteem; and (6) career exploration. The same } \\
\text { workshop was offered on } 2 \text { consecutive days each month to } \\
\text { enhance the opportunity for participation. Each session with the } \\
\text { nurse included a discussion of two of the six topics. }\end{array}$ \\
\hline
\end{tabular}


Table 1. Intervention characteristics of included studies aiming to increase physical activity among adolescent girls ( $\mathrm{k}=34)($ Cont'd/..)

\begin{tabular}{|c|c|c|c|c|}
\hline $\begin{array}{l}\text { Author (year), } \\
\text { country }\end{array}$ & $\begin{array}{l}\text { Intervention } \\
\text { name }\end{array}$ & Design & Participants & Description of intervention and control conditions \\
\hline $\begin{array}{l}\text { Schofield et al., } \\
2005^{89} \text { Australia }\end{array}$ & No name & $\begin{array}{l}\text { Randomised } \\
\text { controlled trial } \\
\text { (school) }\end{array}$ & $\begin{array}{l}\mathrm{N}=85 \text { girls. Mean } \\
\text { age } 15.8 \text { (SD 0.8) } \\
\text { years }\end{array}$ & $\begin{array}{l}\text { Intervention group 1: twelve weekly sessions, with pedometer } \\
\text { based self-monitoring and educative meetings encouraging daily } \\
\text { increases in steps until 10,000/day. Intervention group 2: twelve } \\
\text { weekly sessions, with self-monitoring by recording daily minutes } \\
\text { of MVPA and educative meetings encouraging daily activity by } \\
\text { 10-15 minutes per week until 30-60 minutes per day. Control } \\
\text { group: no intervention. }\end{array}$ \\
\hline $\begin{array}{l}\text { Simon et al., } 2004^{90} \\
\text { France }\end{array}$ & ICAPS & $\begin{array}{l}\text { Randomised } \\
\text { controlled trial } \\
\text { (school) }\end{array}$ & $\begin{array}{l}\mathrm{N}=486 \text { girls. } \\
\text { Mean age } 11.7 \\
(\mathrm{SD} 0.6) \text { years. }\end{array}$ & $\begin{array}{l}\text { Intervention group: } 4 \text { years' duration, in partnership with families } \\
\text { and community groups. Focus on three areas: increasing } \\
\text { knowledge, attitudes, beliefs, and motivation for physical activity } \\
\text { through debates and providing information; social support from } \\
\text { parents, peers, teachers, and physical activity instructors; and } \\
\text { changing environmental conditions for physical activity. } \\
\text { Educational component and new opportunities for physical } \\
\text { activity. Control group: usual health curriculum and physical } \\
\text { education. }\end{array}$ \\
\hline
\end{tabular}


Table 1. Intervention characteristics of included studies aiming to increase physical activity among adolescent girls ( $\mathrm{k}=34)($ Cont'd/..)

\begin{tabular}{|l|l|l|l|l|}
\hline $\begin{array}{l}\text { Author (year), } \\
\text { country }\end{array}$ & $\begin{array}{l}\text { Intervention } \\
\text { name }\end{array}$ & Design & Participants & Description of intervention and control conditions \\
\hline $\begin{array}{l}\text { Taymoori et al., } \\
2008^{92} \text { Iran }\end{array}$ & No name & $\begin{array}{l}\text { Randomised } \\
\text { controlled trial } \\
\text { (school) }\end{array}$ & $\begin{array}{l}\text { N=161 girls. } \\
\text { Mean age 14.79 } \\
\text { (SD 0.44) years }\end{array}$ & $\begin{array}{l}\text { Intervention (THP and HP): baseline, week 4, week 10 and week } \\
\text { sessions, plus individual counselling session at week 10 and week } \\
\text { 18. The THP group also received education on the two processes } \\
\text { of change: counter conditioning and stimulus control. Week 22 } \\
\text { girls received an individual phone call and during week 24 the } \\
\text { intervention groups went mountaineering. Control group received } \\
\text { no intervention. }\end{array}$ \\
\hline $\begin{array}{l}\text { Young et al., 2006 } \\
\text { US }\end{array}$ & No name & $\begin{array}{l}\text { Randomised } \\
\text { controlled trial } \\
\text { (individual) }\end{array}$ & $\begin{array}{l}\text { N=221 girls. } \\
\text { Mean age 13.8 } \\
\text { (SD 0.5) years }\end{array}$ & $\begin{array}{l}\text { Intervention group: one school year programme focusing on } \\
\text { social independence, environmental factors, and problem solving } \\
\text { skills. Delivery during class lectures, small group discussions, } \\
\text { and homework activities. Included physical activity monitoring } \\
\text { and strategies to maximise physical activity during physical } \\
\text { education classes. Families were invited for workshop and } \\
\text { received newsletters and parent-child homework. Control group: } \\
\text { usual curriculum. }\end{array}$ \\
\hline
\end{tabular}


Table 2. Coding Information for Studies meeting Inclusion Criteria

\begin{tabular}{|c|c|c|c|c|c|c|c|c|c|c|c|c|}
\hline \multirow[b]{2}{*}{ Study } & \multicolumn{7}{|c|}{ Intervention Characteristics } & \multicolumn{3}{|c|}{ Sample Characteristics } & \multicolumn{2}{|c|}{\begin{tabular}{|l|} 
Study \\
Characteristics
\end{tabular}} \\
\hline & Type & Focus & $\underline{\text { Level }}$ & $\underline{\text { Time }}$ & $\begin{array}{l}\text { Follow- } \\
\text { up }\end{array}$ & Theory & Quality & Population & Age & Country & Setting & Measure \\
\hline $\begin{array}{l}\text { Bayne-Smith et al., } \\
2004^{54}\end{array}$ & ED & $\mathrm{HH}$ & $\mathrm{C}$ & 1 & $\mathrm{~N}$ & $\mathrm{~A}$ & $\mathrm{~L}$ & GO & $\mathrm{O}$ & US & $\mathrm{S}$ & SR \\
\hline $\begin{array}{l}\text { Bronikowski, } \\
2010^{55}\end{array}$ & ED & $\mathrm{PA}$ & $\mathrm{I}$ & 2 & $\mathrm{Y}$ & $\mathrm{T}$ & $\mathrm{L}$ & BG & $\mathrm{Y}$ & $\mathrm{W}$ & $\mathrm{S}+$ & SR \\
\hline $\begin{array}{l}\text { Bronikowski and } \\
\text { Bronikowski, } \\
2011^{56}\end{array}$ & ED & PA & I & 2 & $\mathrm{Y}$ & $\mathrm{T}$ & $\mathrm{L}$ & BG & $\mathrm{Y}$ & $\mathrm{W}$ & $\mathrm{S}+$ & SR \\
\hline Bush et al., $2010^{57}$ & $\mathrm{EV}$ & OB & $\bar{Y}$ & 2 & $\mathrm{~N}$ & $\mathrm{~A}$ & $\mathrm{~L}$ & BG & $\bar{Y}$ & $\mathrm{~W}$ & $\mathrm{~S}$ & SR \\
\hline $\begin{array}{l}\text { Chin A Paw et al., } \\
2008^{158} 59\end{array}$ & $\mathrm{M}$ & OB & $\mathrm{S}$ & 2 & $\mathrm{Y}$ & $\mathrm{T}$ & $\mathrm{M}$ & BG & $\bar{Y}$ & $\mathrm{~W}$ & $\mathrm{~S}+$ & SR \\
\hline $\begin{array}{l}\text { De Bar et al., } \\
2012^{60}\end{array}$ & ED & PAD & I & 2 & $\mathrm{Y}$ & $\mathrm{A}$ & $\mathrm{H}$ & GO & $\mathrm{Y}$ & US & $\mathrm{C}+$ & SR \\
\hline $\begin{array}{l}\text { Dewar et al., } \\
2013^{61}\end{array}$ & ED & PAS & $\mathrm{S}$ & 2 & $\mathrm{Y}$ & $\mathrm{T}$ & $\mathrm{M}$ & GO & $\mathrm{Y}$ & $\mathrm{W}$ & $\mathrm{S}+$ & $\mathrm{O}$ \\
\hline $\begin{array}{l}\text { Dishman et al., } \\
\text { 2004-05 }{ }^{145-47}\end{array}$ & $\mathrm{M}$ & PA & S & 2 & $\mathrm{~N}$ & $\mathrm{~T}$ & $\mathrm{M}$ & GO & $\mathrm{Y}$ & US & $\mathrm{S}+$ & SR \\
\hline
\end{tabular}


Table 2. Coding Information for Studies meeting Inclusion Criteria (Cont'd/...)

\begin{tabular}{|c|c|c|c|c|c|c|c|c|c|c|c|c|}
\hline \multirow[b]{2}{*}{ Study } & \multicolumn{7}{|c|}{ Intervention Characteristics } & \multicolumn{3}{|c|}{ Sample Characteristics } & \multicolumn{2}{|c|}{$\begin{array}{l}\text { Study } \\
\text { Characteristics }\end{array}$} \\
\hline & Type & Focus & $\underline{\text { Level }}$ & $\underline{\text { Time }}$ & $\begin{array}{l}\text { Follow- } \\
\text { up }\end{array}$ & Theory & Quality & Population & Age & Country & Setting & Measure \\
\hline $\begin{array}{l}\text { Dudley et al., } \\
2010^{62}\end{array}$ & EN & PA & $\mathrm{I}$ & 1 & $\mathrm{~N}$ & $\mathrm{~T}$ & $\mathrm{~L}$ & GO & $\mathrm{O}$ & US & $\mathrm{S}$ & $\mathrm{O}$ \\
\hline $\begin{array}{l}\text { Everhart et al., } \\
2002^{64}\end{array}$ & ED & PA & $\mathrm{I}$ & 2 & $\mathrm{~N}$ & $\mathrm{~A}$ & $\mathrm{~L}$ & BG & $\mathrm{Y}$ & US & S & SR \\
\hline $\begin{array}{l}\text { Faircloth \& } \\
\text { Stratton, 2005-06 } \\
16566\end{array}$ & ED & PA & $\mathrm{C}$ & 2 & $\mathrm{~N}$ & $\mathrm{~A}$ & $\mathrm{~L}$ & GO & $\mathrm{Y}$ & $\mathrm{W}$ & $\mathrm{S}$ & $\mathrm{O}$ \\
\hline $\begin{array}{l}\text { Haerens et al., } \\
2006^{68}\end{array}$ & $\mathrm{M}$ & PAD & $\mathrm{S}$ & 2 & $\mathrm{~N}$ & $\mathrm{~T}$ & M & BG & $\mathrm{Y}$ & $\mathrm{W}$ & $\mathrm{S}+$ & SRO \\
\hline Jago et al., $2012^{69}$ & ED & PA & $\mathrm{S}$ & 1 & $\bar{Y}$ & $\mathrm{~N}$ & $\mathrm{M}$ & GO & $\mathrm{Y}$ & $\mathrm{W}$ & $\mathrm{S}$ & $\mathrm{O}$ \\
\hline $\begin{array}{l}\text { Jamner et al., } 2004 \\
\text { t70-74 }\end{array}$ & $\mathrm{M}$ & PA & S & 2 & $\mathrm{~N}$ & $\mathrm{~A}$ & $\mathrm{~L}$ & GO & $\mathrm{O}$ & US & S & SR \\
\hline
\end{tabular}


Table 2. Coding Information for Studies meeting Inclusion Criteria (Cont'd/...)

\begin{tabular}{|c|c|c|c|c|c|c|c|c|c|c|c|c|}
\hline \multirow[b]{2}{*}{$\underline{\text { Study }}$} & \multicolumn{7}{|c|}{ Intervention Characteristics } & \multicolumn{3}{|c|}{ Sample Characteristics } & \multicolumn{2}{|c|}{$\begin{array}{l}\text { Study } \\
\text { Characteristics }\end{array}$} \\
\hline & Type & Focus & $\underline{\text { Level }}$ & $\underline{\text { Time }}$ & $\begin{array}{l}\text { Follow- } \\
\text { up }\end{array}$ & Theory & Quality & Population & $\underline{\text { Age }}$ & Country & Setting & Measure \\
\hline Jones et al., $2008^{48}$ & $\mathrm{M}$ & PAS & $\mathrm{S}$ & 2 & $\mathrm{~N}$ & $\mathrm{~T}$ & $\mathrm{H}$ & GO & $\mathrm{Y}$ & US & $\mathrm{S}$ & SR \\
\hline $\begin{array}{l}\text { Kelder et al., } 1993 \\
17576\end{array}$ & ED & $\mathrm{HH}$ & $\mathrm{C}$ & 2 & $\mathrm{~N}$ & $\mathrm{~T}$ & $\mathrm{M}$ & BG & $\mathrm{Y}$ & US & $\mathrm{S}+$ & SR \\
\hline $\begin{array}{l}\text { Kilen et al., 1988- } \\
89^{17778}\end{array}$ & ED & $\mathrm{HH}$ & $\mathrm{S}$ & 1 & $\mathrm{Y}$ & $\mathrm{T}$ & $\mathrm{M}$ & BG & $\mathrm{O}$ & US & S & SR \\
\hline $\begin{array}{l}\text { Lubans \& Sylva, } \\
2009^{79}\end{array}$ & ED & PA & $\mathrm{I}$ & 1 & $\mathrm{~N}$ & $\mathrm{~T}$ & $\mathrm{~L}$ & BG & $\mathrm{O}$ & $\mathrm{W}$ & $\mathrm{S}$ & SR \\
\hline $\begin{array}{l}\text { Neumark-Sztainer } \\
\text { et al., } 2003^{83}\end{array}$ & $\mathrm{M}$ & OB & $\mathrm{S}$ & 2 & $\mathrm{Y}$ & $\mathrm{T}$ & $\mathrm{L}$ & GO & $\mathrm{O}$ & US & S & SR \\
\hline $\begin{array}{l}\text { Neumark-Sztainer } \\
\text { et al., } 2010^{84}\end{array}$ & $\mathrm{M}$ & OB & $\mathrm{S}$ & 2 & $\mathrm{Y}$ & $\mathrm{T}$ & $\mathrm{L}$ & GO & $\mathrm{O}$ & US & $S$ & SR \\
\hline
\end{tabular}


Table 2. Coding Information for Studies meeting Inclusion Criteria (Cont'd/...)

\begin{tabular}{|c|c|c|c|c|c|c|c|c|c|c|c|c|}
\hline \multirow[b]{2}{*}{ Study } & \multicolumn{7}{|c|}{ Intervention Characteristics } & \multicolumn{3}{|c|}{ Sample Characteristics } & \multicolumn{2}{|c|}{$\begin{array}{l}\text { Study } \\
\text { Characteristics }\end{array}$} \\
\hline & Type & Focus & $\underline{\text { Level }}$ & $\underline{\text { Time }}$ & $\begin{array}{l}\text { Follow- } \\
\text { up }\end{array}$ & Theory & Quality & Population & $\underline{\text { Age }}$ & Country & Setting & $\underline{\text { Measure }}$ \\
\hline $\begin{array}{l}\text { Patrick et al, } \\
2006^{85}\end{array}$ & ED & PAD & $\mathrm{I}$ & 2 & $\mathrm{~N}$ & $\mathrm{~T}$ & $\mathrm{~L}$ & BG & $\mathrm{O}$ & US & $\mathrm{C}$ & SRO \\
\hline $\begin{array}{l}\text { Robbins et al., } \\
2006^{87}\end{array}$ & ED & PA & $\mathrm{Y}$ & 1 & $\mathrm{~N}$ & A & $\mathrm{H}$ & GO & $\mathrm{O}$ & US & $\mathrm{S}+$ & SR \\
\hline $\begin{array}{l}\text { Robbins et al., } \\
2012^{88}\end{array}$ & ED & PA & S & 2 & $\mathrm{~N}$ & $\mathrm{~T}$ & $\mathrm{M}$ & GO & $\mathrm{Y}$ & US & $\mathrm{S}+$ & $\mathrm{O}$ \\
\hline $\begin{array}{l}\text { Spruijt-Metz et al., } \\
2008^{91}\end{array}$ & ED & PAS & $\mathrm{S}$ & 1 & $\mathrm{Y}$ & $\mathrm{T}$ & $\mathrm{M}$ & GO & $\mathrm{Y}$ & US & $\mathrm{S}$ & SR \\
\hline $\begin{array}{l}\text { Taymoori et al., } \\
2008^{92}\end{array}$ & $\mathrm{M}$ & PA & $\mathrm{S}$ & 2 & $\mathrm{Y}$ & $\mathrm{T}$ & $\mathrm{L}$ & GO & $\mathrm{O}$ & $\mathrm{W}$ & $\mathrm{S}$ & SR \\
\hline
\end{tabular}


Table 2. Coding Information for Studies meeting Inclusion Criteria (Cont'd/...)

\begin{tabular}{|c|c|c|c|c|c|c|c|c|c|c|c|c|}
\hline \multirow[b]{2}{*}{$\underline{\text { Study }}$} & \multicolumn{7}{|c|}{ Intervention Characteristics } & \multicolumn{3}{|c|}{ Sample Characteristics } & \multicolumn{2}{|c|}{$\begin{array}{l}\text { Study } \\
\text { Characteristics }\end{array}$} \\
\hline & Type & Focus & $\underline{\text { Level }}$ & Time & $\begin{array}{l}\text { Follow- } \\
\underline{\text { up }}\end{array}$ & Theory & Quality & Population & Age & Country & Setting & Measure \\
\hline $\begin{array}{l}\text { Winette et al., } \\
1999^{94}\end{array}$ & ED & PAD & $\mathrm{C}$ & 1 & $\mathrm{~N}$ & $\mathrm{~T}$ & $\mathrm{~L}$ & GO & $\mathrm{O}$ & US & $\mathrm{S}+$ & SR \\
\hline $\begin{array}{l}\text { Young et al., } \\
2006^{93}\end{array}$ & ED & PA & $\mathrm{I}$ & 2 & $\mathrm{~N}$ & $\mathrm{~T}$ & $\mathrm{~L}$ & GO & $\mathrm{Y}$ & US & $\mathrm{S}+$ & SR \\
\hline
\end{tabular}

Note. ${ }^{1}$ indicates data was used by multiple studies. Type (Intervention Type): Ed = Educational, En = Environmental, $\mathrm{M}=$ Multicomponent.

Focus (Intervention Focus): $\mathrm{HH}=$ Heart Health, $\mathrm{O}=$ Obesity-Related Behaviors, PA = Physical Activity Only, PAD = Physical Activity AND

Diet, PAS = Physical Activity \& Sedentary Behaviors. Level (Level of Randomization). C = Class, I = Individual, S = School, Y = Year Group.

Time (Intervention Length): 1 = less than or equal to 12 weeks, 2 = greater than 12 weeks. Follow-up (Intervention Follow-Up AFTER Post

Test): N = No, Y = Yes. Theory (Theoretical Foundation): T = Theoretical, A = Atheoretical. Quality (Study Quality): L = Low Delphi score $<$ 3, $\mathrm{M}=$ Moderate Delphi score between 4 and 6, $\mathrm{H}=$ High Quality Delphi Score $>6$. Population (sample composition) BG = Boys and Girls, $\mathrm{GO}=$ Girls Only. Age (Mean age of sample): $\mathrm{O}=$ Older Adolescent mean age $\geq 16$ years, $\mathrm{Y}=$ Younger Adolescent mean age $<16$ years.

Country (Participants Country of Origin): US = United States, W = Rest of World. Setting (Study Setting): C = Community, C $+=$ Community and Parent, S = School-Based, S+ = School and Outside of School. Measure (Study Outcome Measures) O = Objective, OS = Objective \& SelfReport, $\mathrm{S}=$ Self Report. 
Table 3. Adolescent Girl Physical Activity Moderator Analyses

\begin{tabular}{|c|c|c|c|c|c|c|c|c|c|c|}
\hline \multirow[b]{2}{*}{ Moderator Variable } & \multicolumn{5}{|c|}{ Effect Size Statistics } & \multirow{2}{*}{\begin{tabular}{|l|} 
Null \\
Test
\end{tabular}} & \multicolumn{3}{|c|}{ Heterogeneity Statistics } & \multirow{2}{*}{$\begin{array}{l}\begin{array}{l}\text { Publication } \\
\text { Bias }\end{array} \\
\text { Fail Safe } N \\
\end{array}$} \\
\hline & $\underline{\boldsymbol{k}}$ & $\underline{G}$ & $\underline{S E}$ & $\underline{s^{2}}$ & 95\% C.I. & & $Q$ & $\underline{\tau^{2}}$ & $\underline{I}^{2}$ & \\
\hline Random Effects Model $^{A}$ & 34 & 0.350 & 0.115 & 0.013 & $(0.124,0.577)$ & $3.034^{*}$ & $1436.90^{*}$ & 0.421 & 97.70 & 3476 \\
\hline \multicolumn{11}{|l|}{$\begin{array}{l}\text { Intervention } \\
\text { Characteristics }^{B}\end{array}$} \\
\hline Intervention Type & & & & & & & $2.310^{B}$ & & & \\
\hline Educational & 21 & 0.225 & 0.145 & 0.021 & $(-0.060,0.509)$ & 1.547 & & 0.105 & 89.21 & \\
\hline Environmental & 4 & 0.372 & 0.344 & 0.118 & $(-0.301,1.046)$ & 1083 & & 0.130 & 71.60 & \\
\hline Multicomponent & 9 & 0.618 & 0.215 & 0.046 & $(0.197,1.039)$ & $2.877 *$ & & 0.827 & 99.18 & \\
\hline Intervention Focus & & & & & & & $2.715^{B}$ & & & \\
\hline Heart Health & 4 & 0.214 & 0.315 & 0.099 & $(-0.404,0.832)$ & 0.679 & & 0.219 & 97.58 & \\
\hline Obesity Related & 4 & 0.076 & 0.315 & 0.099 & $(-0.541,0.693)$ & 0.241 & & 0.000 & 0.000 & \\
\hline PA and Diet & 6 & 0.220 & 0.272 & 0.074 & $(-0.313,0.753)$ & 0.809 & & 0.029 & 48.46 & \\
\hline PA and Sedentary & 4 & 0.729 & 0.320 & 0.102 & $(0.102,1.356)$ & $2.280 *$ & & 0.786 & 98.32 & \\
\hline PA Only & 16 & 0.410 & 0.164 & 0.027 & $(0.089,0.732)$ & $2.502^{*}$ & & 0.778 & 97.35 & \\
\hline
\end{tabular}


Table 3. Adolescent Girl Physical Activity Moderator Analyses (Cont'd/...)

\begin{tabular}{|c|c|c|c|c|c|c|c|c|c|c|}
\hline \multirow[b]{2}{*}{$\underline{\text { Moderator Variable }}$} & \multicolumn{5}{|c|}{ Effect Size Statistics } & \multirow{2}{*}{\begin{tabular}{|l|} 
Null \\
Test \\
$\underline{Z}$ \\
\end{tabular}} & \multicolumn{3}{|c|}{ Heterogeneity Statistics } & \multirow{2}{*}{$\begin{array}{l}\begin{array}{l}\text { Publication } \\
\text { Bias }\end{array} \\
\text { Fail Safe } N \\
\end{array}$} \\
\hline & $\underline{\boldsymbol{k}}$ & $\underline{G}$ & $\underline{S E}$ & $\underline{s^{2}}$ & 95\% C.I. & & $\underline{Q}$ & $\underline{\tau^{2}}$ & $\underline{I}^{2}$ & \\
\hline Randomisation Level & & & & & & & $1.521^{B}$ & & & \\
\hline Class & 5 & 0.185 & 0.321 & 0.103 & $(-0.443,0.814)$ & 0.578 & & 0.045 & 80.37 & \\
\hline Individual & 9 & 0.281 & 0.249 & 0.062 & $(-0.207,0.769)$ & 1.130 & & 0.010 & 22.60 & \\
\hline School & 18 & 0.472 & 0.170 & 0.029 & $(0.140,0.805)$ & $2.783 *$ & & 0.660 & 98.57 & \\
\hline Year Group & 2 & $\begin{array}{l}- \\
0.072\end{array}$ & 0.518 & 0.269 & $(-1.088,0.944)$ & -0.139 & & 0.000 & 0.000 & \\
\hline Intervention Time & & & & & & & $0.034^{B}$ & & & \\
\hline$\leq 12$ weeks & 10 & 0.384 & 0.218 & 0.048 & $(-0.044,0.812)$ & 1.758 & & 0.201 & 89.95 & \\
\hline$>12$ weeks & 24 & 0.336 & 0.140 & 0.020 & $(0.063,0.610)$ & $2.408^{*}$ & & 0.472 & 98.28 & \\
\hline Intervention Follow-up & & & & & & & $0.128^{B}$ & & & \\
\hline No & 22 & 0.383 & 0.152 & 0.023 & $(0.084,0.681)$ & $2.509 *$ & & 0.639 & 98.27 & \\
\hline Yes & 12 & 0.292 & 0.202 & 0.041 & $(-0.104,0.688)$ & 1.444 & & 0.179 & 94.51 & \\
\hline Theoretical Approach & & & & & & & $0.888^{B}$ & & & \\
\hline
\end{tabular}


Table 3. Adolescent Girl Physical Activity Moderator Analyses (Cont'd/...)

\begin{tabular}{|c|c|c|c|c|c|c|c|c|c|c|}
\hline \multirow[b]{2}{*}{$\underline{\text { Moderator Variable }}$} & \multicolumn{5}{|c|}{ Effect Size Statistics } & \multirow{2}{*}{\begin{tabular}{|l|} 
Null \\
Test \\
$\underline{Z}$ \\
\end{tabular}} & \multicolumn{3}{|c|}{ Heterogeneity Statistics } & \multirow{2}{*}{$\begin{array}{l}\text { Publication } \\
\text { Bias } \\
\text { Fail Safe } N \\
\end{array}$} \\
\hline & $\underline{\boldsymbol{k}}$ & $\underline{G}$ & $\underline{S E}$ & $\underline{s}^{2}$ & 95\% C.I. & & $\underline{Q}$ & $\underline{\tau^{2}}$ & $\underline{I}^{2}$ & \\
\hline Atheoretical & 10 & 0.180 & 0.215 & 0.046 & $(-0.241,0.601)$ & 0.840 & & 0.032 & 59.64 & \\
\hline Theoretical & 24 & 0.422 & 0.140 & 0.020 & $(0.148,0.696)$ & $3.021^{*}$ & & 0.494 & 98.35 & \\
\hline Intervention Quality & & & & & & & $0.637^{B}$ & & & \\
\hline High & 4 & 0.524 & 0.352 & 0.124 & $(-0.166,1.214)$ & 1.489 & & 1.104 & 98.74 & \\
\hline Low & 18 & 0.261 & 0.169 & 0.029 & $(-0.070,0.592)$ & 1.547 & & 0.081 & 79.76 & \\
\hline Moderate & 12 & 0.420 & 0.204 & 0.042 & $(0.020,0.820)$ & $2.058^{*}$ & & 0.577 & 98.98 & \\
\hline \multicolumn{11}{|c|}{ Sample Characteristics ${ }^{B}$} \\
\hline Population & & & & & & & $0.879^{B}$ & & & \\
\hline Boys and Girls & 15 & 0.239 & 0.161 & 0.026 & $(-0.076,0.553)$ & 1.486 & & 0.074 & 90.08 & \\
\hline Girls Only & 19 & 0.439 & 0.142 & 0.020 & $(0.162,0.717)$ & $3.103^{*}$ & & 0.751 & 98.04 & \\
\hline Age & & & & & & & $0.013^{B}$ & & & \\
\hline Older Adolescence & 12 & 0.332 & 0.201 & 0.040 & $(-0.062,0.725)$ & 1.653 & & 0.180 & 91.70 & \\
\hline
\end{tabular}


Table 3. Adolescent Girl Physical Activity Moderator Analyses (Cont'd/...)

\begin{tabular}{|c|c|c|c|c|c|c|c|c|c|c|}
\hline \multirow[b]{2}{*}{ Moderator Variable } & \multicolumn{5}{|c|}{ Effect Size Statistics } & \multirow{2}{*}{\begin{tabular}{|l|} 
Null \\
Test
\end{tabular}} & \multicolumn{3}{|c|}{ Heterogeneity Statistics } & \multirow{2}{*}{$\begin{array}{l}\begin{array}{l}\text { Publication } \\
\text { Bias }\end{array} \\
\text { Fail Safe } N \\
\end{array}$} \\
\hline & $\underline{\boldsymbol{k}}$ & $\underline{G}$ & $\underline{S E}$ & $\underline{s}^{2}$ & 95\% C.I. & & $\underline{Q}$ & $\underline{\tau^{2}}$ & $\underline{I}^{2}$ & \\
\hline Younger Adolescence & 22 & 0.360 & 0.149 & 0.022 & $(0.068,0.651)$ & $2.420^{*}$ & & 0.529 & 98.39 & \\
\hline Country & & & & & & & $0.214^{B}$ & & & \\
\hline World & 13 & 0.278 & 0.196 & 0.038 & $(-0.105,0.662)$ & 1.423 & & 0.075 & 82.56 & \\
\hline US & 21 & 0.394 & 0.153 & 0.023 & $(0.093,0.694)$ & $2.568 *$ & & 0.593 & 98.52 & \\
\hline \multicolumn{11}{|c|}{ Study Characteristics $^{\text {B }}$} \\
\hline Setting & & & & & & & $0.713^{B}$ & & & \\
\hline Community & 1 & 0.110 & 0.820 & 0.672 & $(-1.497,1.717)$ & 0.134 & & 0.000 & 00.00 & \\
\hline Community + Parent & 1 & 0.122 & 0.702 & 0.493 & $(-1.255,1.499)$ & 0.173 & & 0.000 & 00.00 & \\
\hline School & 19 & 0.437 & 0.163 & 0.027 & $(0.117,0.757)$ & $2.680^{*}$ & & 0.354 & 95.56 & \\
\hline School + Outside & 13 & 0.255 & 0.196 & 0.038 & $(-0.130,0.639)$ & 1.298 & & 0.546 & 98.81 & \\
\hline Measure & & & & & & & $0.223^{B}$ & & & \\
\hline
\end{tabular}


Table 3. Adolescent Girl Physical Activity Moderator Analyses (Cont'd/...)

\begin{tabular}{|c|c|c|c|c|c|c|c|c|c|c|}
\hline \multirow[b]{2}{*}{$\underline{\text { Moderator Variable }}$} & \multicolumn{5}{|c|}{ Effect Size Statistics } & \multirow{2}{*}{\begin{tabular}{|l|} 
Null \\
Test
\end{tabular}} & \multicolumn{3}{|c|}{ Heterogeneity Statistics } & \multirow{2}{*}{\begin{tabular}{|l}
$\begin{array}{l}\text { Publication } \\
\text { Bias }\end{array}$ \\
Fail Safe $N$ \\
\end{tabular}} \\
\hline & $\underline{\boldsymbol{k}}$ & $\underline{G}$ & $\underline{S E}$ & $\underline{s}^{2}$ & 95\% C.I. & & $\underline{Q}$ & $\underline{\tau^{2}}$ & $\underline{I}^{2}$ & \\
\hline Objective & 6 & 0.287 & 0.292 & 0.084 & $(-0.282,0.856)$ & 0.988 & & 0.124 & 69.11 & \\
\hline Objective \& Self-Report & 3 & 0.204 & 0.409 & 0.167 & $(-0.598,1.006)$ & 0.498 & & 0.000 & 00.00 & \\
\hline Self-Report & 26 & 0.380 & 0.135 & 0.018 & $(0.115,0.645)$ & $2.808^{*}$ & & 0.456 & 98.31 & \\
\hline
\end{tabular}

Note. $k=$ number of effect sizes. $g=$ effect size (Hedges g). $S E=$ standard error. S2 = variance. 95\% C. $I$. = confidence intervals (lower limit, upper limit). $Z=$ test of null hypothesis. $\tau^{2}=$ between study variance in random effects model. $I^{2}=$ total variance explained by moderator. * indicates $\mathrm{p}<.01$. A $=$ Total $Q$-value used to determine heterogeneity. B = Between $Q$-value used to determine significance $(\alpha<0.01)$. 
Figure 1. Example search strategy run through Science Direct on May $14^{\text {th }} 2013$.

TITLE-ABSTR-KEY((Girls OR children OR adolescents OR youth) AND (school OR family or education OR community)) and TITLE-ABSTR-KEY((intervention OR trial OR controlled trial) AND (physical activity OR activity OR exercise)) 
Figure 2. Flow chart describing the study-identification process

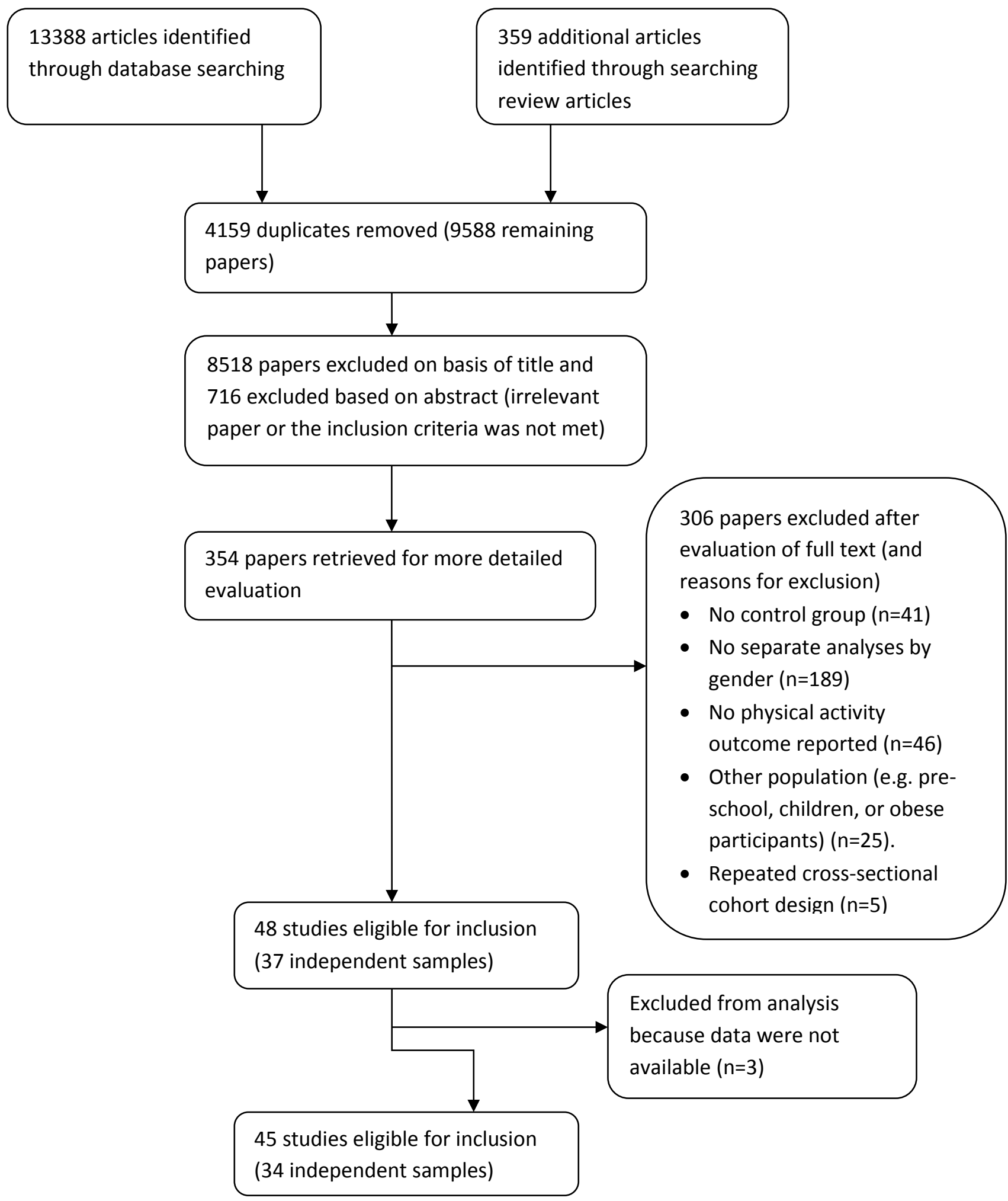




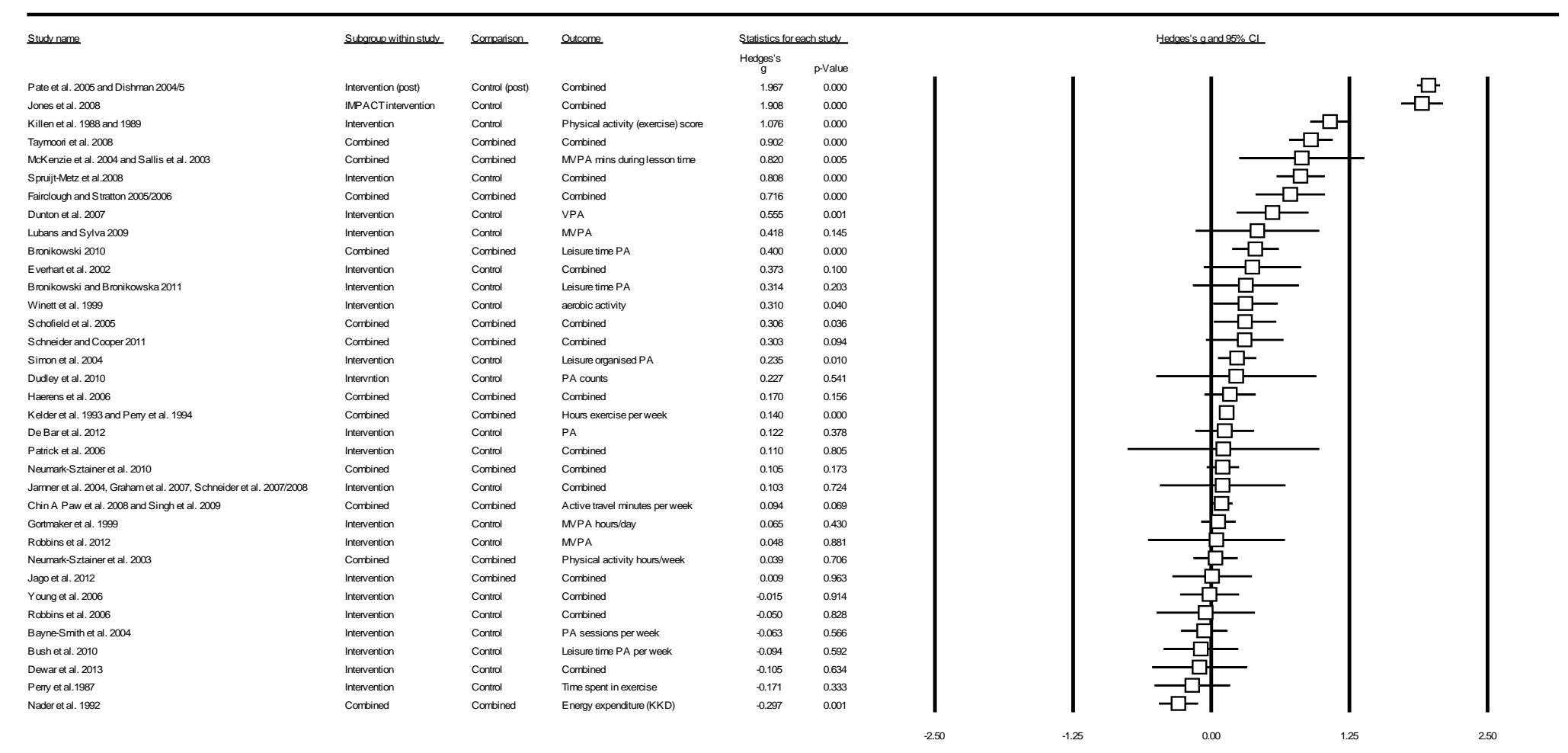

Figure 2: Forest Plot for Adolescent Girls Physical Activity Interventions 